\title{
POCZĄTKI POLSKIEGO MENNICTWA W ŚWIETLE NOWSZYCH BADAŃ ${ }^{1}$
}

\author{
THE ORIGINS OF POLISH COINAGE \\ IN THE LIGHT OF NEW RESEARCH
}

\begin{abstract}
The author updates the knowledge of the origins of coinage in Poland in the late $10^{\text {th }}$ and the early $11^{\text {th }}$ centuries. This is possible owing to new coin finds and new research methods, predominantly discoveries of new die-links. In the conclusions, the author states that coin minting in Poland was not initiated by duke Mieszko I (approx. 962-992) but his son Bolesław the Brave (992-1025). The early coinage was more intense than historians used to think, and more diverse. One mint used, simultaneously, dies with correct legends and dies ineptly copying foreign patterns. The coins were used for manifestation and economic purposes alike. They accounted for a small proportion of the prevailing foreign coins in circulation.
\end{abstract}

Keywords: coins, early coinage, die-links, coin finds, new research, Bolesław the Brave.

Początki polskiego mennictwa to temat żywo interesujący badaczy od co najmniej XIX wieku. Zajmował się nim m.in. Kazimierz Stronczyński w swojej fundamentalnej pracy o polskich monetach dynastii Piastów i Jagiellonów (Stronczyński 1883-1885). Najpełniejszy zestaw typów i odmian najdawniejszych monet polskich, lub za polskie wówczas uważanych, podał Marian Gumowski (Gumowski 1939). Nowy pogląd na pieniądz monetarny i niemonetarny w Polsce wczesnośredniowiecznej (IX-XI w.) przedstawił Ryszard Kiersnowski (Kiersnowski 1960).

O początkach polskiego mennictwa kilkakrotnie wypowiadałem się również i ja - najpełniej przed pół wiekiem w monograficznym opracowaniu polskich monet

* Instytut Archeologii i Etnologii PAN, al. Solidarności 105, 00-140 Warszawa, e-mail: suchodol7@ gmail.com.

${ }^{1}$ Jest to nieco zmieniony, rozszerzony i uaktualniony tekst: S. Suchodolski, The beginnings of Polish coinage in the light of recent research, Wiadomości Numizmatyczne 59, 2015, z. 1-2 (Polish Numismatic News IX, 2015. Special Issue for the XV International Numismatic Congress in Taormina, September 2015), s. 67-94. 
z przełomu X i XI wieku (Suchodolski 1967). Badając cały, dostępny wówczas materiał zgromadzony w krajowych i zagranicznych kolekcjach zarówno publicznych, jak i prywatnych (łącznie 194 egz.), doszedłem do przekonania, że ówczesne mennictwo było słabo rozwinięte i źle zorganizowane. Miał je zapoczątkować już Mieszko I (ok. 960-992) pod koniec swoich rządów, a kontynuować jego syn Bolesław Chrobry (992-1025). Wzajemne proporcje między efektami działalności menniczej obu tych władców najlepiej wyraża liczba przydzielanych im wówczas typów monetarnych - trzy Mieszkowi i piętnaście Bolesławowi (por. tab. 1).

Tabela 1. Bilans znalezisk i monet na przełomie XX i XXI w.

\begin{tabular}{|l|c|c|c|c|}
\hline \multicolumn{1}{|c|}{ Monety i znaleziska } & \multicolumn{2}{c|}{ Do roku 1967} & \multicolumn{2}{c|}{ Do roku 2011} \\
\hline \multirow{2}{*}{ Monety Bolesława Chrobrego } & typy & sztuki & typy & sztuki \\
\cline { 2 - 6 } & 15 & 140 & 17 & ponad 185 \\
\hline Monety z imieniem Mieszka & 3 & 54 & 3 & ponad 75 \\
\hline Znaleziska z monetami polskimi & \multicolumn{3}{|c|}{57} & \multicolumn{3}{c|}{ ponad 90 } \\
\hline
\end{tabular}

W okresie późniejszym kilkakrotnie weryfikowałem powyższy obraz, wykorzystując zarówno przyrost materiału, jak i postęp badań (Suchodolski 1998; 2000b; 2000d; 2009b). Największe znaczenie miały tu dwa czynniki - odkrycia w ziemi nowych depozytów gromadnych, tzw. skarbów (por. Suchodolski, Bogucki 2017), oraz dalsze odkrycia połączeń stempli monetarnych. Skarby te wśród wielu setek monet obcych z X i XI w. przynoszą również nieliczne monety rodzime. Są między nimi zarówno egzemplarze wybite już znanymi dotychczas stemplami, jak i nowymi ich wariantami. Najciekawsze są wszakże okazy należące do typów całkiem nowych, dotychczas nieznanych. We wszystkich tych wypadkach niezmiernie ważny jest kontekst wspomnianych już monet obcych, znacznie lepiej zbadanych i wydatowanych. Na ich podstawie można bowiem weryfikować przyjętą dotychczas chronologię typów monet polskich już znanych i typów nowych.

Osobny problem stanowi ujawnienie znalezisk z polskimi monetami tam, gdzie dotychczas nie były one znane. Do niedawna znaleziska takie rejestrowano jedynie na ziemiach polskich i w Skandynawii. Obecnie coraz częściej wspomina się o nich również na terenach dawnej Rusi².

\footnotetext{
${ }^{2}$ A oto znaleziska z tego obszaru, o których mam informacje: Kipien’ pod St. Petersburgiem, tpq 1024, denar typu REX; Andruszewskij rajon, tpq 1023, denar cały i połówka typu REX; Wasilkowskij rajon, tpq 1019, denar typu INCLITVS, Such. XI,19 oraz nowego typu z kapliczką [por. ryc. 14]; Łuck, tpq 1016, denar typu PRINCES, Such. IX,14, sprzedany w Polsce, Antykwariat Num. M. Niemczyk, Aukcja 5, 2014, nr 12; Grodno, denar z imieniem Mieszka, typ?, jakoby znaleziony luźno. Wszystkie te dane uzyskałem dzięki uprzejmości p. Olega Trostianskiego z miejscowości Czeboksary.

Por. ostatnio: A. R. Mikhelson, O.V. Trost'yansky, Evropeiskie denarii na Rusi v X-XII vekakh, cz. I, Yuzhnaya i yugo-zapadnaya Rus', Sankt-Peterburg 2019, nr 5, 6 i 8. Por. również: Kolodezi, obl. Kaluga, tpq 1059, fragment denara typu PRINCES, Such. IX,15, por. Beliakov, Ianina 1977 (moneta niewykazana w tej publikacji, ale jest przechowywana w zbiorach Państwowego Muzeum
} 
Wszystkie te odkrycia i weryfikacje nie zawsze jednak powodują wzbogacenie naszej bazy źródłowej. Niekiedy sytuacja jest wręcz odwrotna i z rejestru najdawniejszych monet polskich trzeba wyeliminować niektóre typy obce lub późniejsze. Klasycznym przykładem służą tu monety noszące imiona Bolesława i św. Jana przydzielane od dawna Bolesławowi Chrobremu i mennicy wrocławskiej (por. Gumowski 1939, s. 32 i n., nr 22 i 23; Kiersnowski 1960, s. 270 i n.; Suchodolski 1967, s. 122 i n., 179). Co do pochodzenia z Wrocławia, mieszczącego katedrę pod wezwaniem św. Jana Chrzciciela, nie ma wątpliwości. Chronologia znalezisk, w których te monety wystąpiły, niedwuznacznie natomiast wskazuje, że są one znacznie późniejsze. Wybił je inny Bolesław - zapewne Krzywousty (Suchodolski 1996; Nakielski 2012) [ryc. 1].

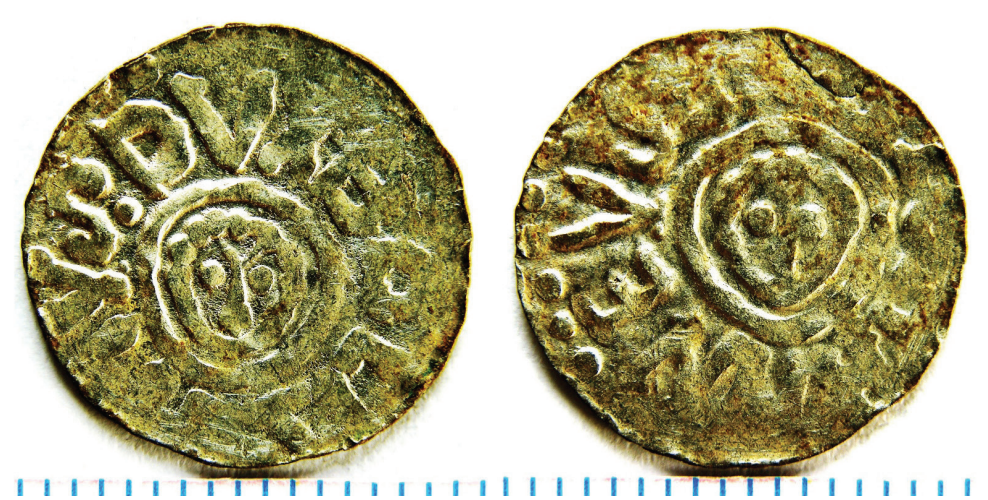

Ryc. 1. Bolesław Krzywousty, mennica Wrocław (wg W. Nakielskiego)

O ile weryfikowanie materiału przez badanie kontekstu znalezisk jest w pełni zrozumiałe i wręcz oczywiste, o tyle korzyści wynikające ze śledzenia tożsamości (lub identyczności) stempli i ich wzajemnych połączeń mogą być niezbyt jasne. Rzecz polega na tym, że do wybicia monety potrzebowano wówczas dwóch stempli - górnego i dolnego - między które wkładano krążek wycięty ze srebrnej blachy. Na skutek uderzenia młotem w stempel górny następowało odbicie na krążku wyobrażeń i napisów wykonanych w negatywie na obu stemplach. Jeśli jednak jednocześnie lub w niewielkim odstępie czasowym używano kilku par stempli, mogło dochodzić do innego ich połączenia niż początkowo planowano. Odmiennym powodem zakłócenia pierwotnego stanu rzeczy było szybsze zniszczenie

Historycznego w Moskwie). W zbiorach tego muzeum jest jeszcze kilkanaście dalszych monet Bolesława Chrobrego i Mieszka, które nie mają metryk pochodzenia (autopsja oraz zdjęcia uprzejmie przekazane przez dr Tatianę Stukalovą z Moskwy i przez p. Jacka Magierę z Krakowa). Jest bardzo prawdopodobne, że monety te wchodziły w skład skarbów znalezionych na terenie byłego Związku Radzieckiego. Por. Stukalova 2005; Magiera, Stukalova 2015a i b. 
stempla górnego, bezpośrednio narażonego na uderzenie młotem, i wskutek tego konieczność wykonania duplikatu.

Historię tych połączeń, a nawet ich kolejność, możemy przedstawić graficznie na tzw. łańcuchach połączeń stempli. W przypadku obszerniejszego i kompletniejszego materiału (w Polsce dopiero od 2. połowy XI w.) łańcuchy te mogą skupiać wiele dziesiątków stempli i obrazować pracę mennicy w ciągu dłuższego czasu (Suchodolski 2012, s. 69-88, tu podstawowa literatura).

W jaki sposób dotychczasowy obraz najdawniejszego mennictwa polskiego uległ zmianom dzięki wykorzystaniu tych dwóch metod? Przede wszystkim okazało się, że monety z imieniem Mieszka występują w skarbach ukrytych stosunkowo późno, gdyż dopiero po 1017 r., czyli ćwierć wieku po śmierci Mieszka I [ryc. 2]. Skoro prawidłowość ta została stwierdzona zarówno dawniej, jak i w now-
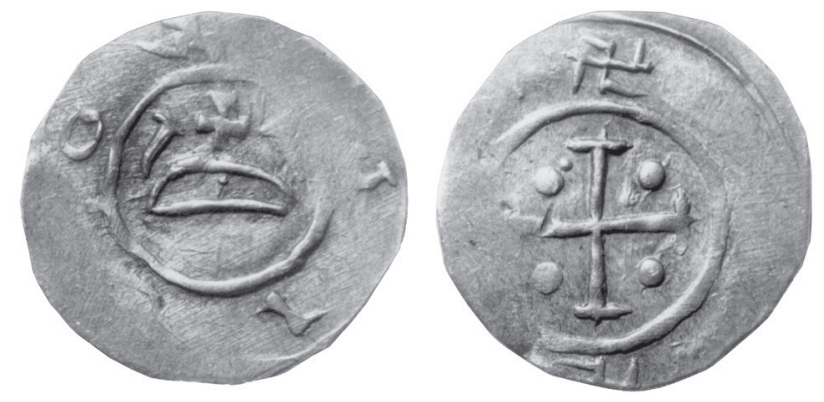

Ryc. 2. Mieszko Bolesławowic, denar z napisem MISICO, mennica Giecz? Śred. 19 mm (z dawnej kolekcji Witolda Korskiego).

szym materiale, nie może być mowy o przypadku. Stąd należy wyciągnąć wniosek, że mamy tu do czynienia z monetami jego wnuka - Mieszka II (1025-1034). Ponieważ jednak monety te pojawiają się w znaleziskach datowanych jeszcze przed 1025 r., tzn. przed objęciem przez niego samodzielnych rządów po śmierci Bolesława Chrobrego, przyjąć trzeba, że Mieszko Bolesławowic prowadził działalność menniczą już jako następca tronu, sprawując u boku ojca ważne funkcje państwowe. Na podstawie rozrzutu znalezisk tych monet można z kolei ustalić, że bito je nie w Krakowie, czyli w wydzielonej mu przez ojca dzielnicy (tak Labuda 1992, s. $41 \mathrm{i} \mathrm{n.),} \mathrm{ale} \mathrm{w} \mathrm{Wielkopolsce.} \mathrm{To} \mathrm{tu} \mathrm{właśnie,} \mathrm{w} \mathrm{centrum} \mathrm{państwa} \mathrm{piastowskiego,}$ prowadzona była również cała działalność mennicza Bolesława Chrobrego. Odbywało się to jednak w różnych miejscowościach, jak można wnioskować na podstawie różnic stylistycznych między stemplami poszczególnych typów monetarnych oraz braku powiązań stempli. W przypadku monet Chrobrego były to zapewne najważniejsze ośrodki, takie jak Gniezno, Poznań i Ostrów Lednicki, ale także mniejsze, jak Mogilno. Mieszko natomiast na miejsce swojej mennicy mógł wybrać 
Giecz, który dobrze nadawał się na zastępczą siedzibę następcy tronu w czasie pobytów w Wielkopolsce. Sam zaś moment rozpoczęcia działalności menniczej Mieszka można hipotetycznie łączyć z 1013 r., kiedy to wzrósł jego prestiż po poślubieniu wnuczki cesarza - Rychezy ${ }^{3}$. Propozycja wyboru Giecza została ostatnio zanegowana przez Przemysława Nowaka, który z kolei domyśla się istnienia mennicy w X/XI w. w Kaliszu (Nowak 2016).

Wyrażona już w 1997 r. moja teza o zmianie atrybucji monet Mieszkowych i opóźnieniu początków polskiego mennictwa (Suchodolski 2000c) została, choć z pewnymi oporami, zaakceptowana przez innych badaczy i weszła do literatury. W konsekwencji najstarszych monet polskich należy upatrywać wśród emisji Bolesława Chrobrego. Kiedy po raz pierwszy o tym pisałem, nie byłem jeszcze pewien, które monety tego władcy postawić na czele jego mennictwa. Wymieniłem tylko grupę typów, które uznałem za najstarsze. Należą do nich monety z imieniem św. Wacława, z imionami Ottona i Adelajdy oraz niedawno odkryte $\mathrm{z}$ wyobrażeniem strzały w Drzewie Życia. Pierwsze z nich łączę z próbą wprowadzenia do Polski kultu świętego męczennika czeskiego - Wacława. Inicjatorem był zapewne blisko z nim spokrewniony przez matkę Bolesław Chrobry, który jeszcze przed rozpoczęciem kultu św. Wojciecha w 997 r. poszukiwał innego patrona państwa i dynastii (Suchodolski 2000a) [ryc. 3].
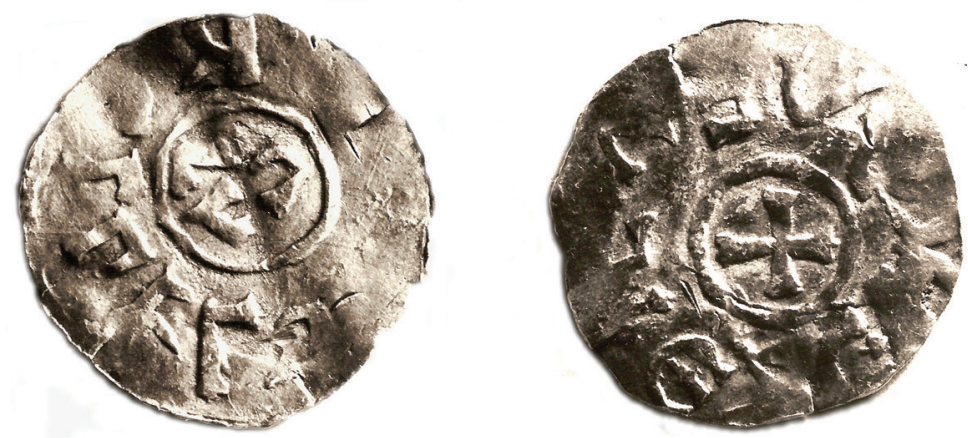

Ryc. 3. Bolesław Chrobry, denar z imieniem św. Wacława, mennica Poznań? Śred. 20 mm. Zbiór Muzeum Narodowego w Pradze, ze skarbu z Lisówka, fot. J. Kouba.

Domysł o wczesnej chronologii monet innego typu - naśladujących saskie denary z imionami cesarza Ottona III (983-1002) i jego babki cesarzowej Adelajdy, opiera się na stosunkowo wczesnym datowaniu skarbów, w których one wystąpiły (po 1002 r.). Nie przesądza to jednak o dacie ich powstania [ryc. 4].

\footnotetext{
${ }^{3} \mathrm{O}$ wynikach ostatnich badań historycznych i archeologicznych w Gieczu por. Kara, Krysztofiak i Wyrwa (red.) 2016.
} 

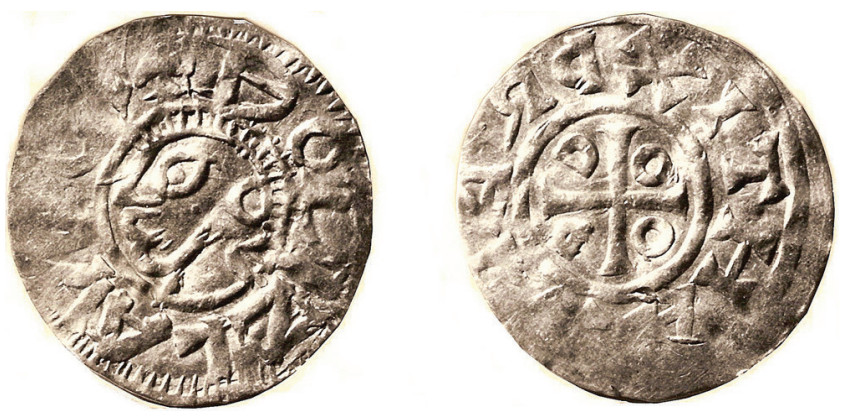

Ryc. 4. Bolesław Chrobry, denar wzorowany na monetach Ottona i Adelajdy (łańcuch 1), mennica Poznań? Śred. 20 mm. Zbiór Muzeum Narodowego w Pradze.
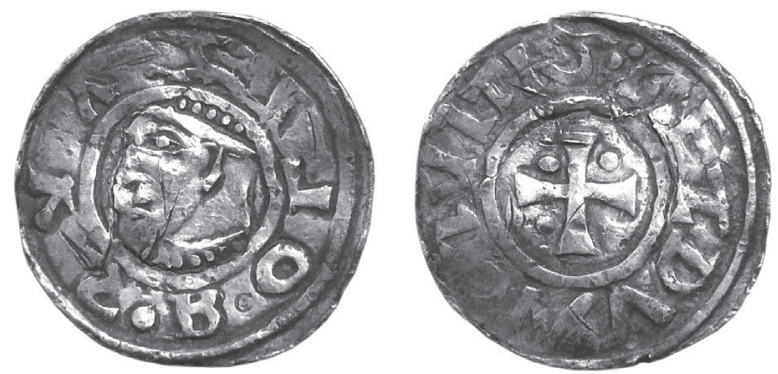

Ryc. 5. Bolesław Chrobry, denar z legendą GNEZDVN CIVITAS. Śred. 18 mm. Zbiór Muzeum Narodowego w Krakowie, fot. M. Bogucki.

Do miana najstarszych monet Bolesława Chrobrego pretendowały również słynne denary z rzekomym portretem władcy i legendą GNEZDVN CIVITAS [ryc. 5]. Zdaniem Andrzeja Schmidta miała ona oznaczać „państwo gnieźnieńskie” i odpowiadać terminowi civitas Schinesghe zawartemu w dokumencie Dagome iudex. W ten sposób Chrobry miał w 992 r. zamanifestować objęcie całej schedy po ojcu (Schmidt 1990). Teza ta jest jednak nie do obronienia, gdyż określenie civitas występuje w tym czasie na licznych monetach europejskich, zwłaszcza kręgu bawarsko-czesko-węgierskiego. Zawsze oznacza ono tam, zgodnie z tradycją karolińską, „miasto” lub „gród”, nigdy zaś „państwo”. Inna rzecz, że Chrobry w momencie obejmowania władzy w państwie istotnie mógł na monecie umieścić nazwę jednego ze swych ośrodków centralnych. Nie da się jednak tego domysłu zweryfikować przez chronologię znalezisk, gdyż analizowana moneta ciągle pozostaje unikatem, który wystąpił w stosunkowo późnym depozycie ukrytym do ziemi dopiero około połowy XI wieku. Wszystkie informacje o odkrywaniu dalszych egzemplarzy tego typu okazały się nieprawdziwe, a same monety - fałszywe (Suchodolski 1999; 2017). 

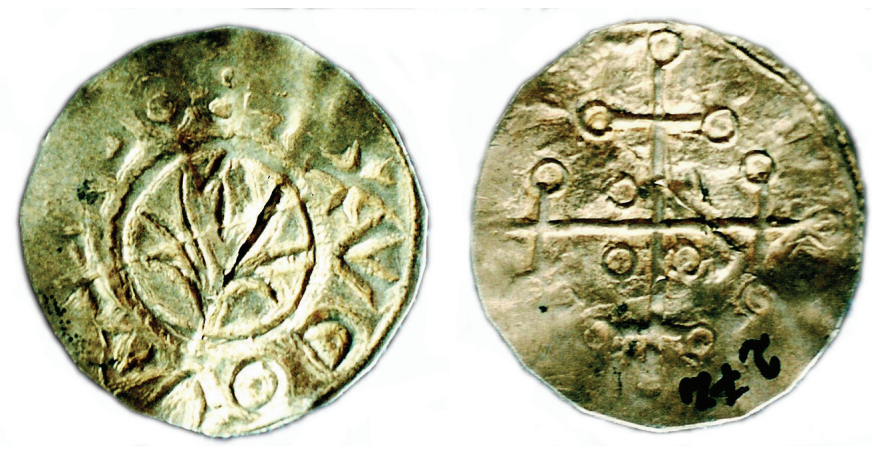

Ryc. 6. Bolesław Chrobry, denar z przedstawieniem strzały, mennica Poznań. Śred. 20 mm. Ze skarbu z Garska, zbiór Muzeum Pomorza Środkowego w Słupsku.

Wśród typów aspirujących do miana najstarszej emisji Bolesława Chrobrego pozostają więc na placu boju monety z wyobrażeniem strzały wśród Drzewa Życia $\mathrm{z}$ jednej strony, a krzyża typu bizantyjskiego $-\mathrm{z}$ drugiej [ryc. 6]. Pierwszy taki okaz znany był już w 1. połowie XIX w., ale został zrabowany przez Rosjan po upadku powstania listopadowego i słuch o nim zaginął. Na podstawie niedokładnego rysunku, a także niezbyt dobrej reputacji jego pierwszego właściciela Tadeusza Wolańskiego, bezkrytycznego słowianofila i miłośnika starożytności - początkowo uznałem, że mamy do czynienia z falsyfikatem. Rehabilitacja monety nastąpiła za sprawą odkrycia nowego egzemplarza w skarbie znalezionym w Kaliszu-Rajskowie (Szczurek i in. 2017, FMP I, nr 97, s. 310, moneta nr 296, Taf. XLVII). Zespół ten zawierał monety wyłącznie z X w., a najpóźniejsza z nich - nie licząc denara Chrobrego - została wybita w latach 985-995. Ten właśnie fakt skłonił mnie do zaliczenia rzeczonego typu do jednego z najstarszych w ramach mennictwa Bolesława Chrobrego (Suchodolski 1997; 2017).

$\mathrm{Na}$ rzecz bezwzględnego starszeństwa monet $\mathrm{z}$ przedstawieniem strzały przemówiło dopiero odkrycie dokonane przez Jerzego Pinińskiego wśród zawartości skarbu z Garska pod Koszalinem. Zespół ten został ukryty niedługo po roku 996, jest zatem drugim pod względem starszeństwa wśród wszystkich depozytów zawierających najdawniejsze monety polskie (Piniński 2002; Horoszko i in. 2016, FMP II, nr 43, s. 167, moneta nr 421, Taf. XXVIII). Typ ten zasługuje więc na to, aby się mu przyjrzeć bliżej. Na awersie, czyli na stronie głównej, widzimy, jak już była o tym mowa, wyobrażenie strzały zakończonej grotem. Wystaje ona z wiązki nieregularnych linii, które można utożsamiać z mocno stylizowanym Drzewem Życia. Strzała natomiast, dążąc niezawodnie do celu, symbolizuje zapewne Słowo Boże. Inna interpretacja, zaproponowana niedawno przez Jerzego Pinińskiego, jest mniej przekonująca. Zdaniem tego badacza jest to nie strzała, lecz włócznia. Miałaby ona symbolizować św. Wojciecha poprzez narzędzie jego męczeńskiej śmierci (Piniński 2010). Podobne wyobrażenie włóczni występuje wpraw- 
dzie na ówczesnych monetach, ale w ręku człowieka, a nie jako samodzielny motyw. Wyjątkiem jest włócznia węgierska św. Stefana, jako jego insygnium koronacyjne, ale wygląda ona zupełnie inaczej (Suchodolski 2005; 2017).

W otoku biegnie wstecz kompletny i w pełni czytelny napis zawierający imię księcia i jego tytuł: + BOLIZLAVO DVX. Forma imienia z końcówką $o$ nie jest błędna, gdyż występuje również we współczesnych tekstach św. Brunona z Querfurtu (Epistola Brunonis). Można się domyślać, że powstała ona przez upodobnienie do imienia Mieszko (Misico). Tytuł książęcy nie jest wyjątkiem na najstarszych monetach polskich, ale też nie jest tam powszechny. Nie występuje na innych monetach z grupy najstarszej. Później pojawia się sporadycznie - w typie o charakterze czeskim z zaskakującą legendą MOGILN CIVITAS (Ginter 1998) ${ }^{4}$ [ryc. 7] lub w rozszerzonej formie: DVX INCLITVS.
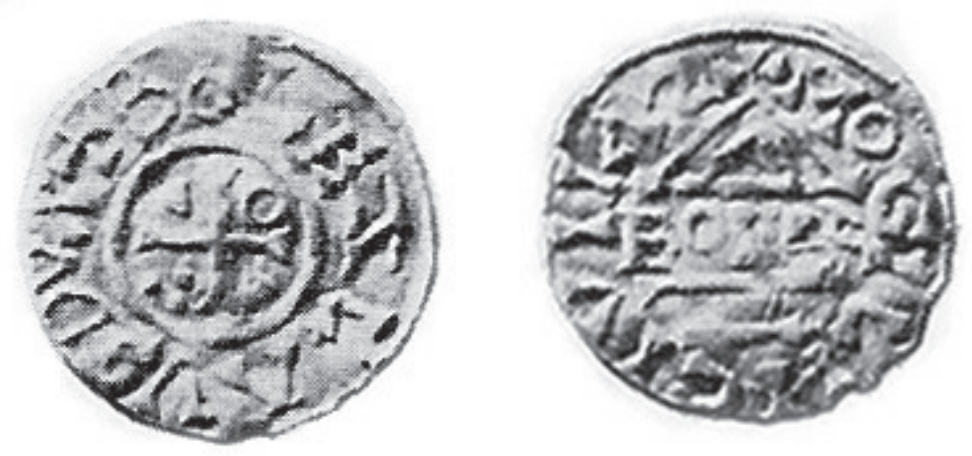

Ryc. 7. Bolesław Chrobry, denar z legendą MOGILN CIVITAS, mennica Mogilno (wg V. Katza). Śred. 20 mm, zbiór Muzeum Narodowego w Pradze

Strona odwrotna, czyli rewers, jest całkowicie anepigraficzna, czyli pozbawiona napisu, co nie znajduje analogii na innych monetach polskich $\mathrm{z}$ tego czasu. $\mathrm{W}$ rezultacie całą powierzchnię stempla zajmuje duże wyobrażenie krzyża z przekrzyżowanymi końcami ramion lub czterech połączonych krzyży łacińskich. Na końcu każdego ramienia umieszczono kółko i jeszcze dodatkowo cztery kółka w kątach ramion. Taki krzyż nazywany jest popularnie podwójnym albo bizantyjskim, ponieważ występuje na bizantyjskich miliarensach, poczynając od połowy $\mathrm{X}$ wieku. $\mathrm{Na}$ polskie monety dostał się on jednak niewątpliwie za pośrednictwem duńskim. W identycznej formie widoczny jest na tzw. półbrakteatach z Hedeby typu Kors

\footnotetext{
${ }^{4}$ Typ ten był pierwotnie zaliczany do monet czeskich. Na ten temat Stróżyk 2009. Nie ma uzasadnienia podjęta przez autora ponowna próba wiązania tych monet z Mogilnem na Łużycach. Por. ostatnio Polanský 2017 (autor błędnie identyfikuje miejscowość, w której znaleziono denar oznaczony jako nr 2 - nie chodzi tu bowiem o Dobrzykowo w pow. gryfickim na Pomorzu, ale o Dobrzyków pod Płockiem, Gorlińska i in. 2015, FMP III, nr 30; denar nr 8 pochodzi ze skarbu znalezionego w okolicach Barlinka, pow. myśliborski na Pomorzu Zachodnim).
} 
(= krzyż), w rzeczywistości bitych w północnej Jutlandii w latach 980-990. Interesujące jest, że również przedstawienie $\mathrm{z}$ awersu ma pewne analogie na monetach duńskich, choć nieco późniejszych, bo Knuta Wielkiego. Występuje na nich podobne przedstawienie Drzewa Życia, z którego wyrasta jednak nie strzała, lecz krzyż.

Okazuje się więc, że u początków polskiego mennictwa stoją jakieś związki z Danią (Suchodolski 2010). Trudno powiedzieć, na czym one polegały. Nie było to jednak chyba wyłącznie naśladownictwo duńskich monet, mimo że występują one w polskich znaleziskach. Możliwość taka oczywiście dotyczy tylko starszych monet duńskich. Wpływ monet Knuta, jako młodszych, nie wchodzi tu w ogóle $\mathrm{w}$ rachubę. Ważne jest jednak podobne kształtowanie symboli w mniej więcej zbliżonym czasie i na niezbyt odległych obszarach. Dlatego bardziej prawdopodobne wydają się jakieś związki międzyludzkie, o których zresztą mówią nieliczne źródła pisane i coraz liczniejsze źródła archeologiczne. Wystarczy przypomnieć, że siostra Chrobrego była najpierw żoną króla szwedzkiego Eryka, a następnie (od ok. 995-996) króla duńskiego Swena Widłobrodego. W konsekwencji została matką króla szwedzkiego Olafa Skötkonunga, a potem króla duńskiego i anglosaskiego Knuta Wielkiego (Jasiński 1992, s. 94-100). Wiadomo również, że ojciec Swena - Harald Sinozęby po nieudanym starciu z opozycją schronił się w pomorskim Wolinie, gdzie też zakończył życie z odniesionych ran. O pobycie Duńczyków w państwie Piastów można domyślać się z kolei na podstawie odkryć niektórych, łączonych z nimi grobów komorowych na wielkopolskich cmentarzyskach w Sowinkach, Dziekanowicach nad Jeziorem Lednickim czy w Bodzi i Kałdusie (Stanisławski 2013; Moździoch, Stanisławski i Wiszewski [red.] 2013). Autorem wzorów stempli, a zwłaszcza legendy, musiał być oczywiście jakiś duchowny związany z capellą książęcą lub biskupem poznańskim. W obu przypadkach za najbardziej prawdopodobne miejsce powstania najstarszej monety polskiej można uważać Poznań.

$\mathrm{Na}$ temat tego typu monetarnego ostatnio zabrał głos również Przemysław Urbańczyk. Przyjmuje on moją interpretację i chronologię, pisząc jednak, że nie była to ,akcja ekonomiczna, zmierzająca do wprowadzenia na rynek gwarantowanych przez władcę środków pieniężnych, lecz zabieg propagandowy. Chodziło o zademonstrowanie monarszego statusu młodego władcy, co było gestem skierowanym raczej na zewnątrz niż do mieszkańców jego państwa..." (Urbańczyk 2017, s. 80-81). Nie przeszkodziło to jednak autorowi kilka stron dalej snuć kolejne, niestety, zupełnie nieprawdopodobne domysły, w dodatku całkowicie sprzeczne z poprzednimi. Jego zdaniem monety te mogły powstać w Danii z inicjatywy Swena Widłobrodego i stanowić prezent dla jego szwagra, to znaczy Bolesława Chrobrego, kiedy Swen żenił się z jego siostrą Świętosławą-Sygrydą. Przy okazji wysunięta została kolejna, równie karkołomna hipoteza. P. Urbańczyk sugeruje, że Swen, chcąc upokorzyć polskiego władcę, nazwał go księciem, podczas kiedy sam tytułował się królem (Urbańczyk 2017, s. 86-88). Historia mennictwa nie zna przy- 


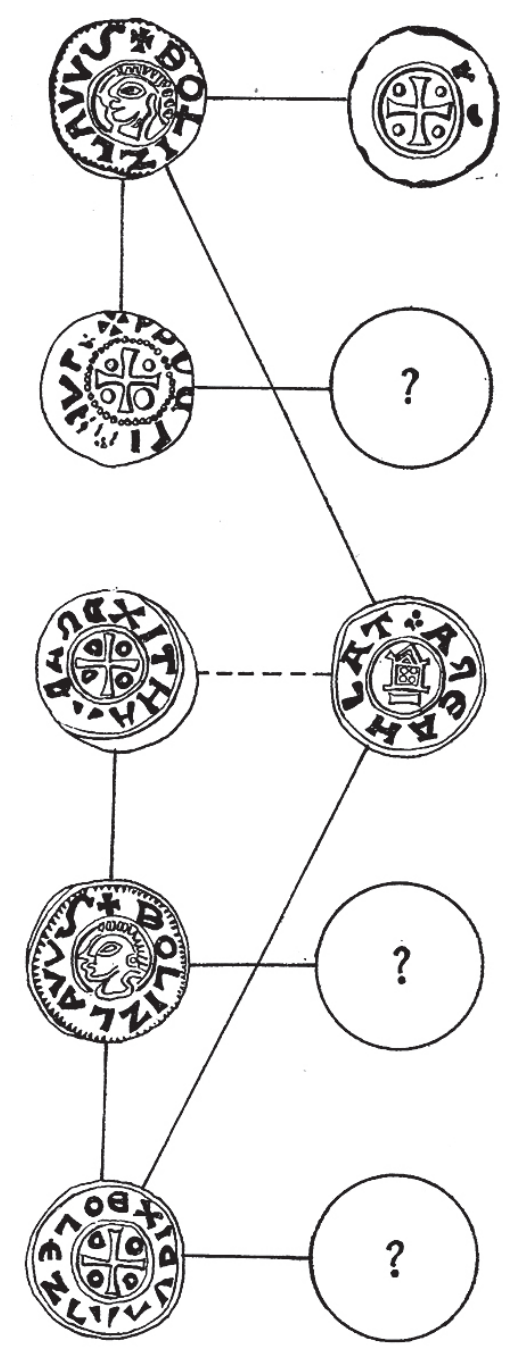

Ryc. 8. Łańcuch 1 połączeń stempli, Poznań? padków tego rodzaju prezentów, które w dodatku miałyby upokorzyć obdarowanych. Istniały natomiast tzw. donatywy, czyli efektowne monety złote lub srebrne, bite oczywiście pod stemplem donatora, a nie odbiorcy ${ }^{5}$.

A jaką nową wiedzę o najdawniejszym mennictwie przyniosły skrupulatne badania stempli menniczych i ich nowych połączeń? Wzbogaceniu uległy trzy już dawniej znane łańcuchy [ryc. 8-10]. Na ich podstawie można było wykazać, że w tych samych mennicach, czy może ostrożniej mówiąc - warsztatach menniczych, wybijane były dwa, zasadniczo różniące się rodzaje monet. Jedne $\mathrm{z}$ nich nosiły rodzime stemple zaopatrzone w imiona i tytuły Bolesława Chrobrego i jego syna Mieszka Bolesławowica, czyli późniejszego króla Mieszka II. A oto, jakie legendy i wyobrażenia się na nich pojawiają:

BOLIZLAVO DVX; strzała w Drzewie Życia i krzyż typu bizantyjskiego; najstarsza moneta polska (ryc. 6).

BOLIZLAVVS; głowa z profilu i krzyż; łańcuch 1 (ryc. 4 i 8).

BOLIZAVS - GNEZDVN CIVITAS; głowa w diademie i krzyż (ryc. 5).

BOLEZLAVS DVX - MOGILN CIVITAS; krzyż i kaplica (ryc. 7).

PRINCES POLONIE (obustronnie); paw i krzyż; łańcuch 2 (ryc. 9 i 15).

${ }^{5}$ We wspomnianej pracy autor wielokrotnie powołuje się na źródła numizmatyczne, opierając się na wynikach nowszych badań (np. Urbańczyk 2017, 10, 98-101, 104-105 i 154, 121-123, 154-156, 174, 183-184, 229 i 233-234, 243-248, 278-280, 293-295 i 333, 303, 331). Rzecz jednak w tym, że na tych ustaleniach nie poprzestaje, ale stara się je wzbogacić o nowe hipotezy, które niestety nie wytrzymują krytyki naukowej. I tak na przykład na podstawie występujących na monetach Chrobrego imion obcych władców - cesarza Ottona III i jego babki Adelajdy, czy księcia czeskiego Władywoja - wnioskuje o relacjach z nimi polskiego emitenta. Nie uwzględnia zatem faktu, że te obce imiona trafiły na polskie monety w wyniku kopiowania stempli monet niemieckich, czeskich, a nawet anglosaskich $\mathrm{z}$ tego powodu, że one w tym czasie najliczniej obiegały w Polsce. Nie były to więc przyczyny polityczne, ale gospodarcze. Por. też dalej. 


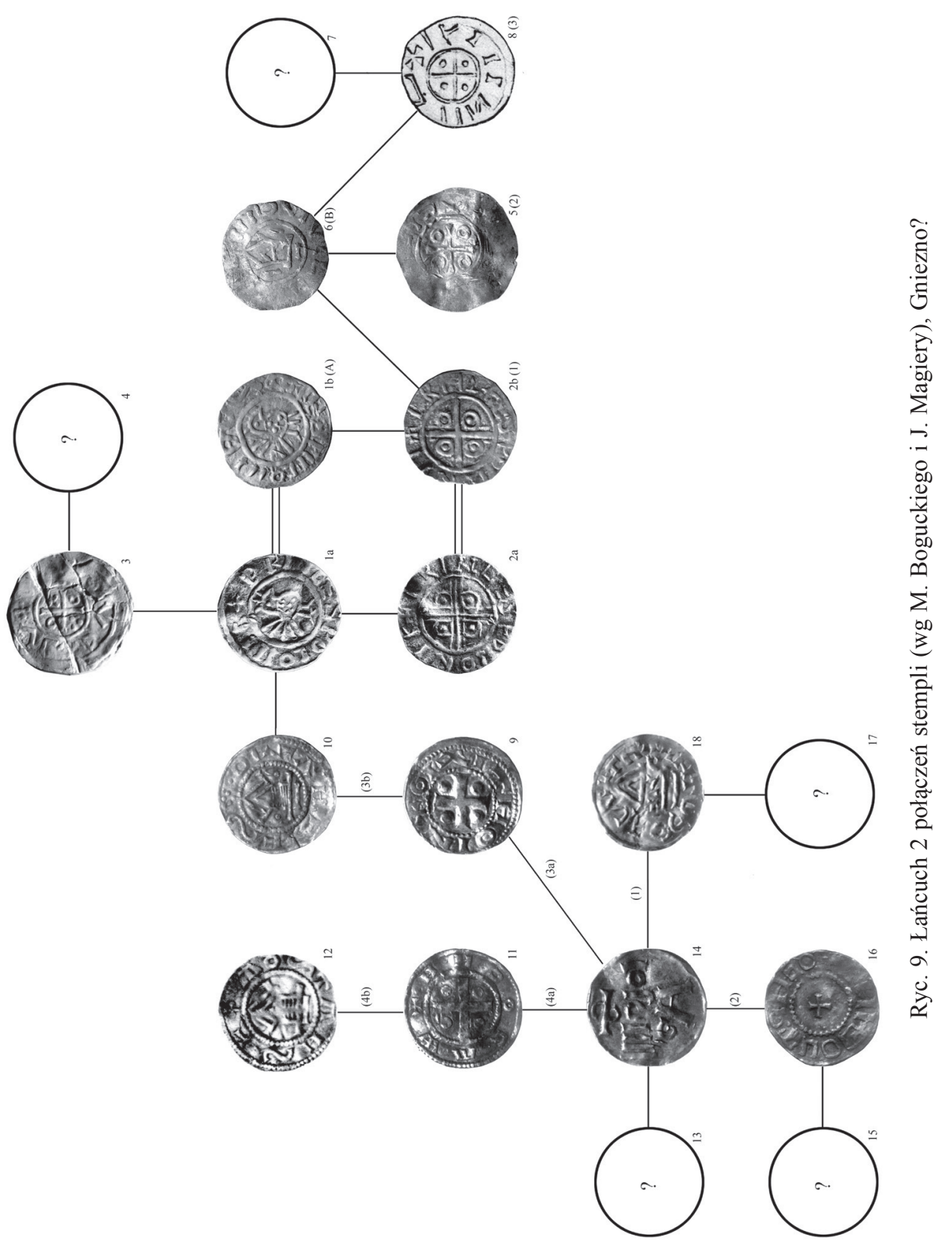


BOLIZLAVS DVX - INCLITVS; popiersie i krzyż; łańcuch 3 (ryc. 10).

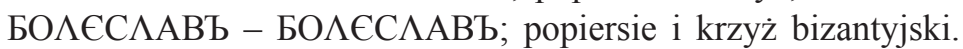

MISICO; szczyt kaplicy i krzyż (ryc. 2). Moneta Mieszka Bolesławowica.

Monety drugiego rodzaju natomiast lepiej lub gorzej kopiowały stemple różnych monet obcych. Wśród nich rozpoznano następujące wzory: saski (Ottona III i cesarzowej Adelajdy), bawarski (księcia Henryka IV i króla Henryka II), koloński (Ottona II i III), czeski (Bolesława III i Władywoja) oraz anglosaski (Etelreda II, mincerz Thurstan z Yorku). Oto ich legendy i wyobrażenia:

AREAHLAT - ODDO i w otoku napis pomylony; kaplica i krzyż; łańcuch 1 (ryc. 8).

VL $\Lambda \mathrm{DVO}[\mathrm{I} \mathrm{D}] \mathrm{V}+$ - ?; krzyż; łańcuch 2 (ryc. 9, nr 3).

S/COLONIA/A - ?; łańcuch 2 (ryc. 9, nr 14).

ÆĐELRED REX ATGO - ĐVRSTAN M-O EOFR; popiersie i krzyż; łańcuch 3 (ryc. 12 i 10, nr 3 i 4).

Nie ma wątpliwości, że ten drugi rodzaj monet, które można nazwać naśladowczymi, był emitowany wyłącznie z powodów ekonomicznych. Kopiowały one najbardziej rozpowszechnione i już zadomowione na polskim rynku monety obce. A skoro nie zawierały żadnych informacji o rzeczywistych emitentach - Bolesławie i Mieszku - nie mogły w żadnym razie pełnić funkcji manifestacyjnych czy propagandowych. Do tego właśnie służyły monety noszące prawdziwe dane metrykalne - imiona książąt polskich, ich tytulaturę, symboliczne wizerunki, a wyjątkowo też nazwy miejscowości, w których dokonywano emisji. Jak już wyżej powiedziano, stemple obu tych rodzajów monet wzajemnie się łączą (zob. łańcuchy 1-3). Tylko dzięki temu dowiedzieliśmy się, że niektóre monety naśladowcze są polskiego pochodzenia.

Nie do końca jednak wiadomo, kiedy i w jaki sposób dochodziło do tych połączeń. Istnieją bowiem dwie możliwości wyjaśnienia tego zjawiska. Zachodziło ono albo w mennicy, z powodu zatrudniania personelu o bardzo zróżnicowanych kwalifikacjach, albo też poza mennicą. Inaczej mówiąc, poprawne stemple musiałyby zostać ukradzione lub zrabowane i następnie użytkowane wespół z dorabianymi, często znacznie gorszymi stemplami ${ }^{6}$. Trudno sobie wyobrazić, aby takie fakty zachodziły w czasie silnych rządów Bolesława Chrobrego. Bardziej prawdopodobne byłyby one po zabójstwie Mieszka II w 1034 r., łączącym się z tym chaosem w państwie, powstaniem ludowym i upadkiem pierwszej monarchii piastowskiej. Analiza chronologii hybryd, czyli monet bitych nieprawidłowo połączonymi stemplami, wykazuje jednak na podstawie chronologii skarbów, w których wystąpiły, że tak późna datacja jest nieprawdopodobna. Również przykład wczesnego mennictwa szwedzkiego wskazuje, że możliwe jest równoczesne używanie

\footnotetext{
${ }^{6}$ Przypadki takie są znane $\mathrm{z}$ okresu Wędrówek Ludów. Także w łańcuchach połączeń stempli monet pomorskich z XI w. rozpoznano obecność oryginalnych stempli duńskich. Por. Bogucki, Magiera 2015b. Autorzy są zdania, że przekazanie tych stempli odbyło się na drodze pokojowej, w ramach aliansów politycznych.
} 
w jednej mennicy stempli rodzimych i naśladowczych, a nawet obcych. W tym ostatnim przypadku chodzi o oryginalne stemple, przywiezione przez anglosaskich mincerzy, którzy znaleźli zatrudnienie w mennicy w Sigtunie (Malmer 1989; 1997; Blackburn 1985; Suchodolski 1971, s. 168 i n.).

Jak jednak w polskich mennicach mogło dochodzić do łączenia stempli tak silnie zróżnicowanych? Istnieją bowiem dwie możliwości: albo początkowo bito oddzielnie monety $\mathrm{z}$ imionami książąt polskich oraz monety naśladowcze i dopiero później mieszano oba rodzaje stempli, albo też od początku łączono je ze sobą. Za drugą z tych możliwości mógł przemawiać fakt, że nie były znane wszystkie pary stempli monet naśladowczych. I tak awers pensa króla anglosaskiego Ethelreda II łączył się ze stemplami monet $\mathrm{z}$ inskrypcją DVX INCLITVS oraz ze stemplami typu bawarskiego [ryc. 10A, nr 3, 1, 6 i 7]. Brak jednak było rewersu typu anglosaskiego i awersu typu bawarskiego. Ten ostatni został już dawniej odkryty w skarbie z Krakowa VIII-Nowej Huty (Suchodolski 1967, s. 101, 173; Reyman-Walczak 2013 [FMP IVA], s. 73, nr 46, 494-496)

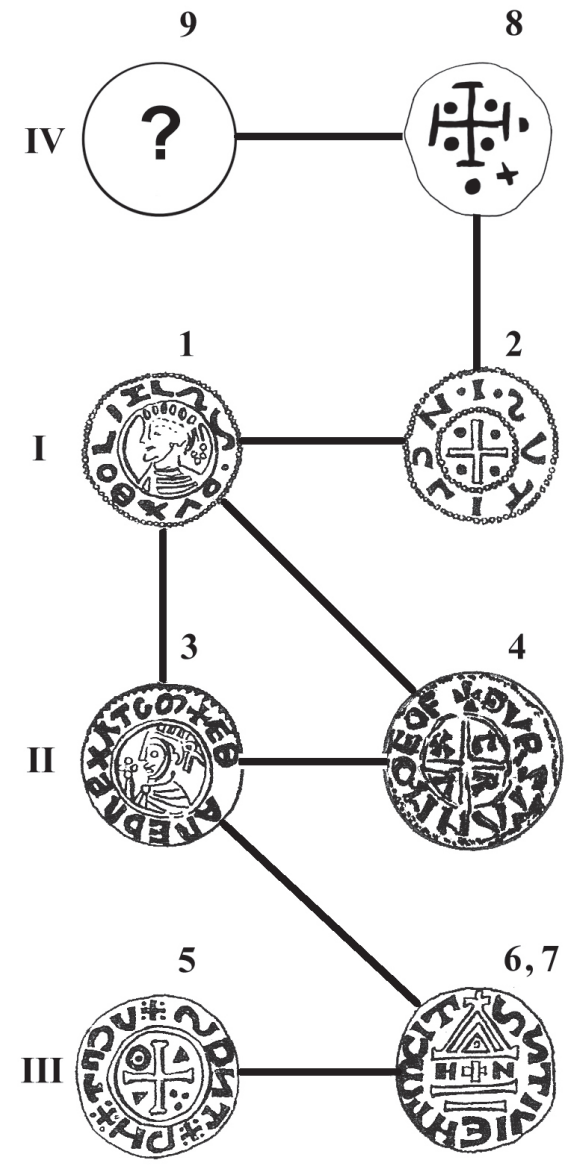

Ryc. 10A. Łańcuch 3 połączeń stempli, Poznań?

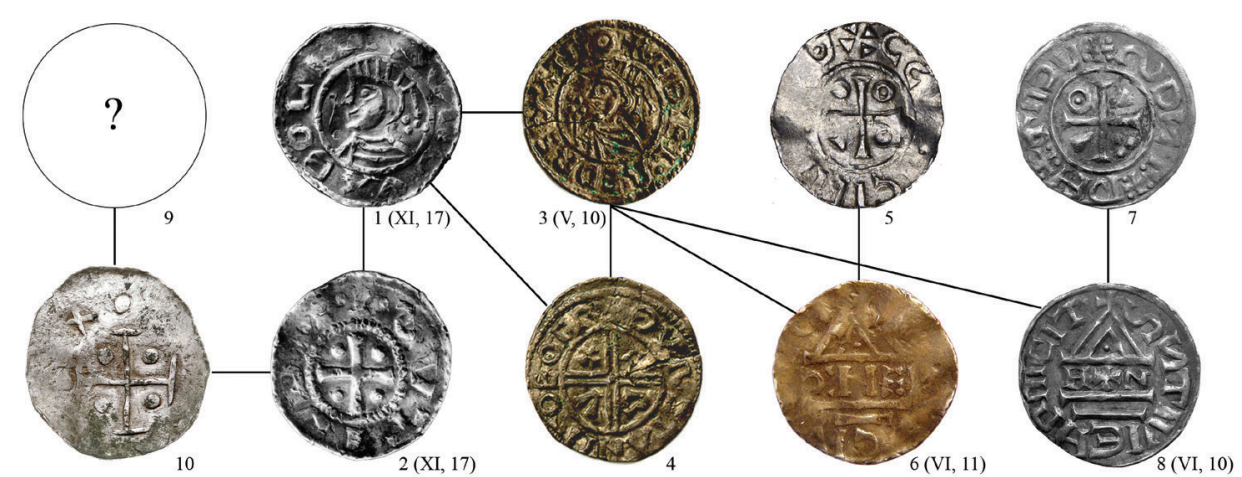

Ryc. 10B. Łańcuch 3 połączeń stempli (wg M. Boguckiego i J. Magiery, po uzupełnieniach) 

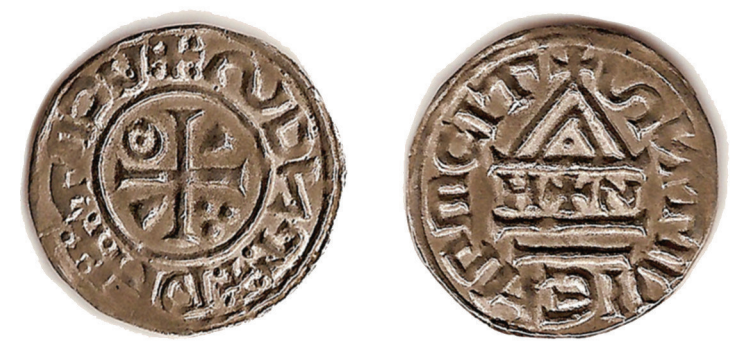

Ryc. 11. Bolesław Chrobry, denar naśladowczy typu bawarskiego (łańcuch 3). Śred. 20 mm, ze skarbu z Nowej Huty-Pleszowa (Kraków VII). Zbiór Muzeum Archeologicznego w Krakowie
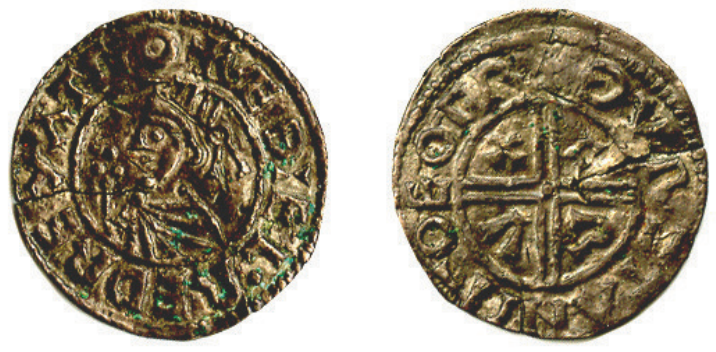

Ryc. 12. Bolesław Chrobry, denar naśladowczy typu anglosaskiego (łańcuch 3, wg K. Jonssona i S. Suchodolskiego)
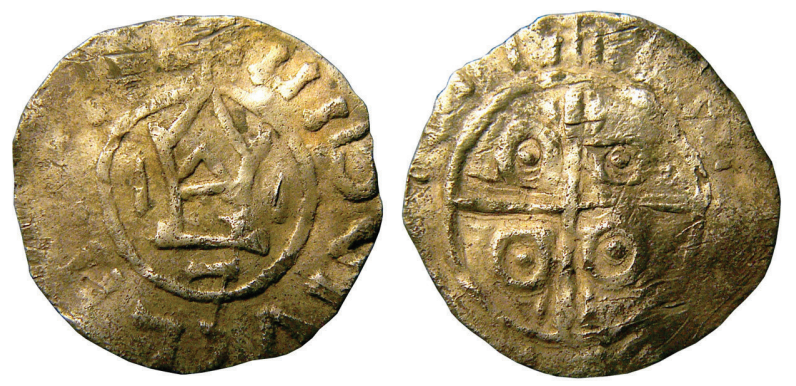

Ryc. 13. Bolesław Chrobry, hybryda typu PRINCES i nowego typu z kapliczką (łańcuch 2, wg M. Boguckiego) 

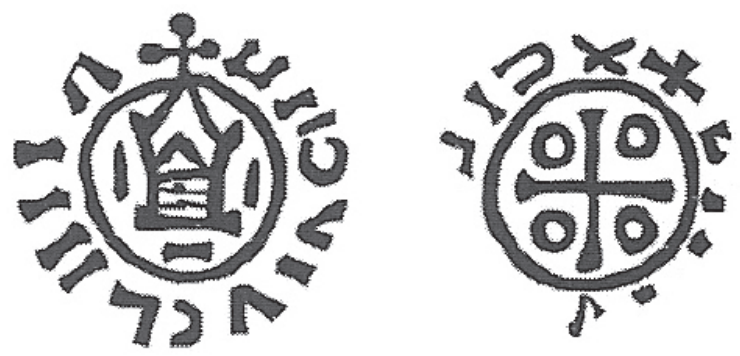

Ryc. 14. Bolesław Chrobry, denar naśladowczy, sprymitywizowany, nowego typu z kapliczką (łańcuch 2, wg M. Boguckiego)

[ryc. 10A, nr 5; ryc. 11]. Przed paroma laty, dzięki współpracy międzynarodowej, odnaleziono również dwie monety z poszukiwanym naśladownictwem rewersu pensa Ethelreda II (Jonsson, Suchodolski 2009) [ryc. 10A, nr 4; ryc. 12]. Przechyla to szalę na korzyść tezy, iż pierwotnie wszystkie naśladownictwa były bite odpowiednimi dla nich parami stempli.

Do takiego wniosku doszli też niedawno inni badacze, którzy odkryli dalszy stempel typu bawarskiego, rozszerzający jeszcze omawiany łańcuch powiązań. Chodzi o drugi, brakujący stempel awersu naśladujący denary ratyzbońskie Henryka. Tym jednak razem jest to starsza odmiana, powstała jeszcze za książęcych rządów (995-1002) Henryka, przyszłego cesarza (Bogucki, Magiera 2015, s. 123 n., ryc. 3 i 5) [ryc. 10B, nr 5-6]. Ostatnio zostało ujawnione połączenie stempli obu tych odmian (WCN 2019, Aukcja Nr 72/2019, nr 91) [Ryc. 10B, 7/6].

Jeszcze bardziej interesujące było odkrycie przez tych badaczy stempla naśladującego rewers denara przypisywanego przez nas Mieszkowi Bolesławowicowi (dawniej typ II,3), co znakomicie potwierdza tę hipotezę i ostatecznie chyba oddala wcześniejsze przekonanie o przynależności tych monet do Mieszka I [ryc. 2, $10 \mathrm{~A}$ i B, 16].

Nie mniejsze znaczenie ma inne odkrycie, jakiego dokonał Mateusz Bogucki. Otóż udało mu się stwierdzić, że w łańcuchu nr 2 stemple typu PRINCES POLONIE łączą się nie tylko z dobrze wykonanymi stemplami naśladowczymi, ale również ze stemplami mocno zbarbaryzowanymi, noszącymi pseudolegendy [ryc. 9, nr 6; ryc. 13 i 14]. Konstatacja ta otworzyła zupełnie nowe możliwości oceny najdawniejszego mennictwa polskiego. Okazało się bowiem, że różnego rodzaju emisje o mocno sprymitywizowanych stemplach, które dotychczas były wiązane $\mathrm{z}$ jakimiś pokątnymi, na poły legalnymi warsztatami, mogły w istocie wyjść z tych samych warsztatów, w których powstawały najbardziej prestiżowe denary Bolesława Chrobrego (Bogucki 2006). Wynika z tego, że rozmiary mennictwa pierwszych Piastów mogły być większe niż się dotychczas sądziło, a jednocześnie poziom wykonania książęcych monet niższy od powszechnie przyjmowanego. 

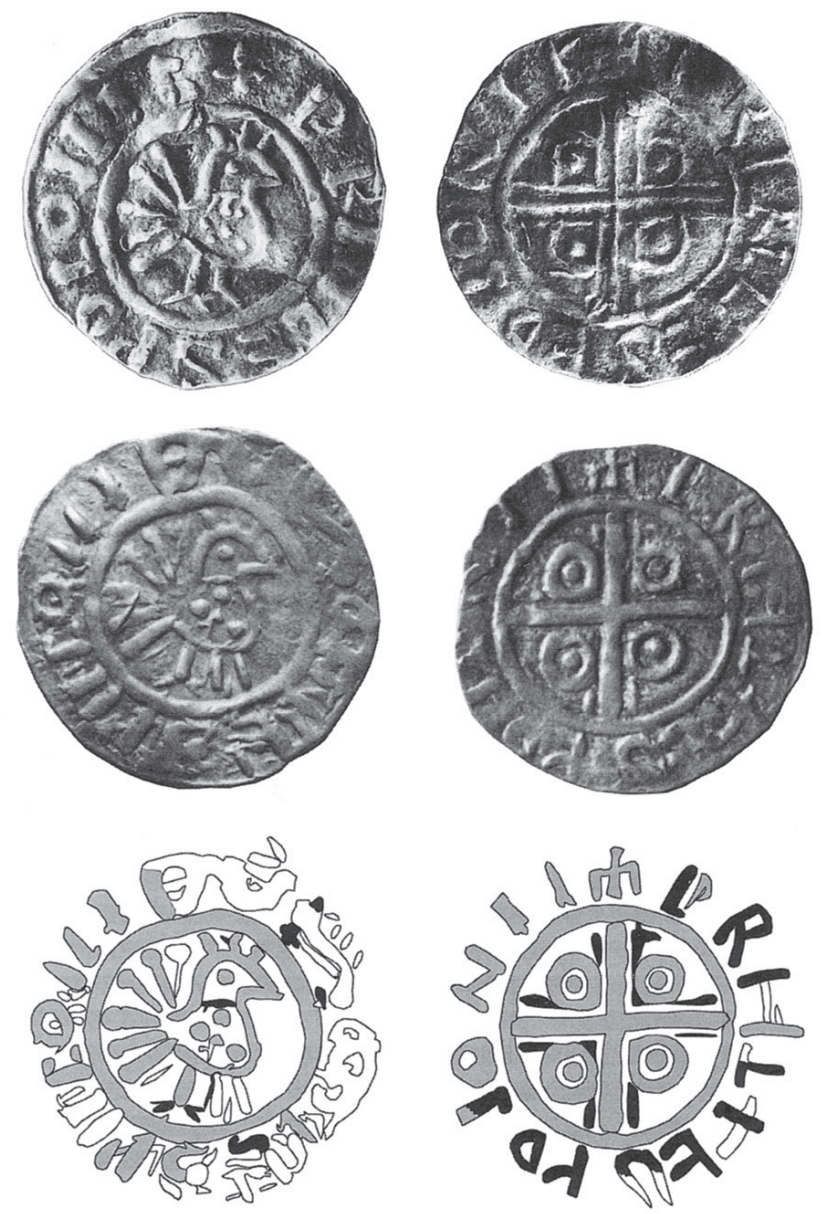

Ryc. 15. Bolesław Chrobry, denar z legendą PRINCES POLONIE, a. stempel pierwotny, b. stempel naprawiony, c. rekonstrukcja poprawek (kolor czarny - fragmenty autentyczne, kolor szary - fragmenty pogłębione i poprawione, kolor biały - nowe elementy (wg M. Boguckiego)

Polskie pochodzenie różnego rodzaju monet naśladujących wzory monet bawarskich, saskich i kolońskich sugerował już dawniej Peter Ilisch. Przedstawił on też łańcuchy wzajemnych połączeń stempli tych naśladownictw (Ilisch 1994; 2005). Ostatnio udało się Mateuszowi Boguckiemu i Jackowi Magierze potwierdzić ten domysł dzięki odkryciu łącznika między jednym z tych łańcuchów a łańcuchem nr 2 połączeń stempli Bolesława Chrobrego (Ilisch 2005, s. 192, nr 3b; Bogucki, 
Magiera 2015, s. 116-120, ryc. 1; Magiera, Stukalova 2015b) [ryc. 9, nr 1a/10]. Dzięki temu odkryciu i tak już duży łańcuch nr 2 jeszcze znacznie zwiększył swoje rozmiary. Mamy jednak powody, aby spodziewać się jego dalszego wzrostu. Brak tu bowiem jeszcze stempla rewersu monety $\mathrm{z}$ imieniem czeskiego księcia Władywoja (nr 4). Dotychczas znane jest naśladownictwo tylko awersu tej monety, łączące się ze stemplami monet Bolesława Chrobrego z legendą PRINCES POLONIE [ryc. 9, nr 3/1a]. Na odnalezienie czekają również awersy monet typu kolońskiego [ryc. 9, nr 13], bawarskiego (nr 17) i bliżej nieokreślonego z małym krzyżem (nr 15).

O ile odkrycia nowych stempli bez wątpienia świadczą o tym, że rozmiary polskiego mennictwa w X/XI w. były większe niż dawniej przypuszczano, o tyle istnieją również przesłanki wskazujące na ocenę wręcz przeciwstawną. O eliminacji typów późniejszych była mowa już poprzednio. Wyniki najnowszych badań Mateusza Boguckiego wskazują, że redukcji powinna ulec również ocena liczby najstarszych stempli menniczych. Badacz ten wykazał, że nie istnieją dwie odmiany stemplowe słynnego denara $z$ legendą PRINCES POLONIE - poprawna i zbarbaryzowana. W rzeczywistości była tylko jedna para stempli, które po częściowym zniszczeniu, może na skutek skorodowania, zostały niezbyt fortunnie naprawione. Naprawy tej dokonał analfabeta, niepotrafiący zrekonstruować liter, ale też nie rozumiejący treści wyobrażenia. W rezultacie po „poprawieniu” ptak został wyposażony w dodatkową, trzecią nogę [ryc. 15]. Zdaniem Mateusza Boguckiego podobnej naprawie, polegającej na spiłowaniu powierzchni zużytego stempla i pogłębieniu zarysów liter i wyobrażeń, miała zostać poddana również para stempli z imieniem Mieszka [ryc. 2]. Nie było więc dwóch odmian: z legendą MISICO i MIDICO, ale tylko jedna, która została naprawiona $\mathrm{z}$ niewielkim tylko błędem (Bogucki 2010). Z podobnymi zabiegami mającymi przedłużyć funkcjonowanie tłoków menniczych trzeba się liczyć również w przypadku innych typów monetarnych Bolesława Chrobrego, np. z legendami: BOLIZLAVS, DVX INCLITVS czy БО $\Lambda € С \Lambda \mathrm{ABЪ}^{7}$.

Powyższe obserwacje pozwalają nam wniknąć w organizację pracy ówczesnych mincerzy. Okazuje się, że mieli oni trudności techniczne z wytwarzaniem nowych stempli. Stare bowiem niekiedy eksploatowali do ostateczności, starając się maksymalnie przedłużyć ich żywot. Podobna jest wymowa zjawiska nieznanego gdzie indziej $\mathrm{w}$ tym czasie, a mianowicie rozdzielanie jednej pary stempli i osobnego użytkowania stempla górnego i stempla dolnego. Rezultatem było bicie monet jednostronnych, mających tylko awers lub tylko rewers. Można było dzięki temu podwoić produkcję menniczą przy użyciu tych samych narzędzi. Symptomatyczne

${ }^{7}$ Uderza np. duże podobieństwo stempli awersów w typie IV,4 i IV,5, 6, 8 [ryc. 4 i 8] oraz obu stempli w typach XI, 18 i 19; XIII, 21 i 22 . Trudno obecnie rozstrzygnąć, czy jest to wynikiem odnowienia tłoków, czy tylko korzystania z tych samych wzorców lub kopiowania stempli zużytych. O monetach z cyrylickim napisem por. ostatnio Kollinger 2014, s. 352-369 i Garbaczewski 2015 oraz polemika: Suchodolski 2018a. 
jest wreszcie posługiwanie się $\mathrm{w}$ oficjalnym książęcym warsztacie menniczym stemplami zupełnie uproszczonymi. Widać, że z braku bardziej fachowych rytowników w razie pilnej potrzeby zatrudniano ludzi przypadkowych o miernych kwalifikacjach. Interesujące jest jednak, że proceder ten stosowano tylko przy produkcji monet niektórych typów. Na pierwszym miejscu stoi typ z legendą PRINCES POLONIE, znany już z nieumiejętnego naprawiania stempli i połączeń ze stemplami zbarbaryzowanymi [ryc. 15]. Ta intensywna eksploatacja stempli zaowocowała największą liczbą zachowanych do naszych czasów egzemplarzy monet. Przed ponad dziesięcioma laty doliczyłem się ich 86 . Obecnie ich liczba przekracza zapewne setkę. Znacznie rzadsze są natomiast monety dwóch innych typów reprezentowanych przez okazy zarówno jedno- jak i dwustronne, a mianowicie z imieniem św. Wacława [ryc. 3] i tytułem REX (Suchodolski 1967, s. 170 i 174 i n.; 2002b).

Jak widać, nasza wiedza o najdawniejszych monetach polskich uległa w ostatnim czasie dużemu wzbogaceniu. Nie znaczy to oczywiście, że teraz już wiemy o nich wszystko. Tym niemniej obecnie łatwiej będzie szukać odpowiedzi na ciągle nasuwające się pytania dotyczące funkcjonowania mennictwa: jak przedstawiało się ono w czasie i w przestrzeni i przede wszystkim jak działało ono w praktyce. Jak już wiemy, w tych samych warsztatach używano bardzo zróżnicowanych stempli $-\mathrm{z}$ imionami władców rodzimych i obcych, w dodatku poprawnych lub bardzo uproszczonych. Mogłoby się wydawać, że najstarsze są pierwsze $\mathrm{z}$ nich, o aktualnych, dobrze wykonanych stemplach, do których dołączano stemple naśladowcze, z upływem czasu coraz gorszej jakości. Bliższa analiza chronologiczna wskazuje, że wcale tak nie musiało być.

Pierwszy łańcuch połączeń, skupiający monety naśladujące wzory saskie, ma najstarszą metrykę [ryc. 4 i 8]. Znalazły się w nim denary z imieniem Bolesława i schematycznym wyobrażeniem jego głowy (tylko inspirowane przez bardzo popularne w znaleziskach denary Ottona III i Adelajdy) oraz niemal wierne kopie tych ostatnich monet. Na podstawie typologii tych monet oraz chronologii znalezisk, w których występują, łańcuch ten można datować na sam koniec $\mathrm{X}$ w. lub pierwsze lata następnego stulecia ${ }^{8}$.

W drugim łańcuchu połączeń monety z legendą PRINCES POLONIE okazały się późniejsze niż pierwotnie sądzono. Powstały one nie około roku $1000 \mathrm{w}$ związku z przybyciem do Gniezna cesarza Ottona III, jak to się nadal często utrzymuje, lecz dopiero w latach 1005-1015. Starsze od nich wydają się denary naśladujące wzory księcia czeskiego Władywoja (1002-1003), a także - jak wskazuje chronologia znalezisk - owe wytwory najbardziej sprymityzowane. Najmłodsze są denary jednostronne, bite „naprawionymi” stemplami (por. Bogucki 2006; Bogucki,

${ }^{8} \mathrm{~W}$ czasie ponownego badania skarbu z Ulejna Peter Ilisch z Münster (gdzie zespół ten jest przechowywany) odkrył nową odmianę monety Bolesława Chrobrego. Dzięki temu można było rozszerzyć omawiany łańcuch połączeń stempli, por. Ilisch, Suchodolski 2003. 
Magiera 2015a, s. 116-120). Zróżnicowaną chronologię (około 980-1020) mają według Petera Ilischa wzorce kolońskie, bawarskie i saskie polskich naśladownictw, które ostatnio zostały włączone do tego łańcucha (Ilisch 2005) [ryc. 9 i 15]. Oczywiście trzeba jednak brać również pod uwagę możliwość, że monety obce były kopiowane z mniejszym lub większym opóźnieniem.

Również w trzecim łańcuchu połączeń [ryc. 10A i B] opóźnieniu uległo datowanie denarów z legendą DVX INCLITVS oraz z legendą naśladującą pensy Ethelreda II. Ich anglosaskie wzory powstały bowiem dopiero około 1013/14 r. (Jonsson, Suchodolski 2009, s. 36 i n.). Starsze natomiast są naśladownictwa typu bawarskiego - denarów króla Henryka II (1002-1009), a zwłaszcza księcia Henryka IV (995-1002) (Bogucki, Magiera 2015, s. 121-123).

Skoro mamy do czynienia z trzema odrębnymi łańcuchami połączeń niewykazującymi związków między sobą, można się domyślać, że obrazują one działalność albo odrębnych mennic, albo tej samej mennicy, ale w różnym czasie. Jeżeli domysł, że autorem wzorów stempli z legendą PRINCES POLONIE i wyobrażeniem pawia był arcybiskup Radzim Gaudenty, jest zgodny z prawdą, to łańcuch 2, w którym występują stemple tych monet, należałoby łączyć z Gnieznem (Suchodolski 2002a, s. 164-167; 2012, s. 304 i n.; 2014). Niemal współczesne lub niewiele późniejsze stemple skupione w polsko-anglosasko-bawarskim łańcuchu 3 (m.in. DVX INCLITVS, Ethelred) musiałyby więc powstać gdzie indziej, chyba w Poznaniu. Tu również należałoby zlokalizować wcześniejszą produkcję menniczą o wzorach saskich, zobrazowaną przez łańcuch $\mathrm{nr} 1$, choć również w łańcuchu 2 pojawily się sprymityzowane stemple o tych samych motywach [ryc. 9, $\mathrm{nr}$ 5/6]. Do Poznania już wcześniej odnieśliśmy typ najstarszy z wyobrażeniem strzały, rozpoczynający oficjalne mennictwo polskie. Tu też byłoby najwłaściwsze miejsce dla typu lansującego kult św. Wacława. Z kolei monety z legendą GNEZDVN CIVITAS najstosowniej jest wiązać z Gnieznem, a z legendą MOGILN CIVITAS - z Mogilnem. Już wcześniej była mowa, że denary Mieszka Bolesławowica mogły powstać w Gieczu. Brak przesłanek dla zlokalizowania miejsca powstania monet $\mathrm{z}$ imieniem Bolesława $\mathrm{i}$ wyobrażeniem jego głowy na wprost, a także dla najpóźniejszych monet pierwszej monarchii $-\mathrm{z}$ pretensyjnym tytułem królewskim i z legendą cyrylicką. Powstały one zapewne dopiero około 1020 roku. Tylko hipotetycznie można by pierwsze $\mathrm{z}$ nich odnieść do Gniezna, a to z powodu jednostronnego ich bicia, a także $\mathrm{z}$ uwagi na fakt, że tu właśnie odbyła się później koronacja królewska. Próbę przydziału typów monetarnych do poszczególnych mennic przedstawia tabela 2 .

Poza problemami dotyczącymi węziej lub szerzej pojmowanego mennictwa literatura zajmowała się $\mathrm{w}$ ostatnich latach również ikonografią najdawniejszych monet polskich. Jak już wyżej wspomniano, padła nieprzekonywająca propozycja, aby na najstarszych monetach Bolesława Chrobrego wyobrażenie uważane przeze mnie za strzałę interpretować jako włócznię - symbol męczeńskiej śmierci św. Wojciecha (Piniński 2010) [ryc. 6]. 

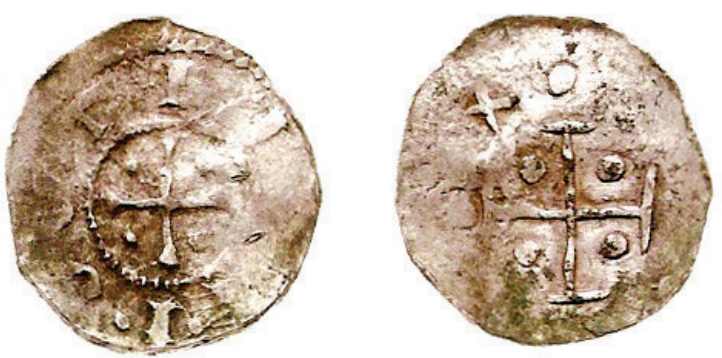

Ryc. 16. Bolesław Chrobry, hybryda typu INCLITVS i imitacji monety Mieszka (wg WCN 56/112)

Tabela 2. Próba przyporządkowania typów do poszczególnych mennic

\begin{tabular}{|c|c|c|c|c|c|}
\hline \multirow{2}{*}{ Lata } & \multicolumn{5}{|c|}{ Mennice } \\
\hline & Poznań & Gniezno & Mogilno & Giecz & ? \\
\hline $992-1000$ & $\begin{array}{l}\text { ze strzałą, } \\
\text { VENCIEZLAVS }\end{array}$ & & & & \\
\hline $995-1005$ & $\begin{array}{l}\text { Łańcuch } 1 \\
\text { a/ BOLIZLAVS } \\
\text { b/ Otto i Adelajda }\end{array}$ & & & & \\
\hline 1000 & & GNEZDVN & & & \\
\hline $1000-1010$ & $\begin{array}{l}\text { Łańcuch } 3 \\
\text { a/ typ bawarski }\end{array}$ & $\begin{array}{l}\text { Łańcuch } 2 \\
\text { a/ VLADIVOI } \\
\text { b/ z kapliczką } \\
\text { c/ PRINCES }\end{array}$ & MOGILN & & popiersie en face \\
\hline $1010-1020$ & $\begin{array}{l}\text { b/ INCLITVS } \\
\text { c/ Ethelred }\end{array}$ & $\begin{array}{c}\text { d/ PRINCES } \\
\text { poprawiony }\end{array}$ & & Mieszko & \\
\hline $1015-1020$ & $\mathrm{~d} /$ ",Mieszko" & REX & & & БО $\Lambda € С \Lambda \mathrm{ABЬ}$ \\
\hline
\end{tabular}

Ostrzejsza dyskusja rozgorzała wokół identyfikacji i interpretacji ptaka wyobrażonego na monetach z legendą PRINCES POLONIE [ryc. 15]. Mój pogląd, że mamy tu do czynienia z przedstawieniem pawia, który symbolizuje życie wieczne - w domyśle zmarłego niedawno św. Wojciecha, został zakwestionowany najpierw przez Tomasza Panfila, a następnie bardzo żywiołowo przez M.D. Kossowskiego. Uważają oni, że jest to Orzeł Biały, w dodatku ukoronowany, symbol suwerenności państwa polskiego (Suchodolski 2002a; Panfil 2002; Kossowski 2007; 2008; 2010). Ta zupełnie anachroniczna teza spotkała się już z ostrą krytyką (Suchodolski 2009a; Garbaczewski 2010). Widoczna tutaj kontrowersja między zwolennikami orła i zwolennikami pawia zdaje się polegać na tym, że ci pierwsi przystąpili 
do interpretacji źródeł numizmatycznych ze z góry już założonym rozwiązaniem, szukając tylko dla niego uzasadnienia. Dla tych drugich natomiast monety stanowią punkt wyjścia do badań, w których oczywiście wykorzystuje się następnie również i inne źródła.

Równie nieudana była interpretacja kopulastego wyobrażenia na denarach Mieszka Bolesławowica [ryc. 1]. Powszechnie uważa się, że to motyw architektoniczny - szczyt świątyni wzorowany na saskich monetach z X wieku. Zdaniem Pawła Stróżyka miałby to być symbol władzy - starolechicka mitra (Stróżyk 2000). Pogląd ten został przedstawiony w atrakcyjny sposób, niestety jednak nie ma żadnego racjonalnego uzasadnienia. Nie jest wszakże wyłączone, że do dyskusji nad interpretacją tego motywu trzeba będzie jeszcze wrócić. Stanie się tak, jeśli w świetle nowych znalezisk lub weryfikacji dawnych okaże się, że monety z imieniem Mieszka powstały po 1025 roku.

Jak w świetle nowych źródeł i dalszych badań przedstawia się nam obecnie najdawniejsze mennictwo polskie i czym nowo uzyskany obraz różni się od tego, jaki mieliśmy w 1967 roku? Widoczny jest znaczny przyrost podstawy źródłowej. Ogólny bilans został przedstawiony w tabeli 1 . A do podanych tutaj danych należy jeszcze dodać coraz liczniej ujawniane monety obustronnie imitujące obce wzory i dlatego do niedawna w ogóle nierozpoznane (por. Ilisch 2005; Bogucki 2006; 2012b).

Najbardziej rzuca się w oczy opóźnienie początków mennictwa. Jeszcze raz trzeba jednak zastrzec, że dotyczy to wyłącznie monet niejako oficjalnych, tzn. noszących imiona władców rodzimych lub imiona władców obcych, ale tylko w przypadku, gdy stemple tych ostatnich monet były powiązane ze stemplami tych pierwszych. Istnieje wszakże możliwość, że jakieś monety naśladowcze bił już Mieszko I, ale na pewno nie były to te okazy, które mu do niedawna przypisywano.

Ogólna ocena tego wczesnego mennictwa nie uległa zasadniczej zmianie. Nadal sądzimy, że było ono mocno ograniczone pod względem wielkości emisji. Przekonania tego nie zmienia odkrycie co najmniej trzech nowych typów i możliwość włączenia do mennictwa książęcego większej liczby prymitywnych naśladownictw. Poza tym można się domyślać, że niektóre stemple były wykorzystywane niezbyt intensywnie. Świadczy o tym bardzo niewielka liczba zachowanych do dzisiaj okazów, wśród których są też unikaty. Były więc zapewne wybite w niewielkiej tylko liczbie egzemplarzy. Znaczący jest również fakt, że najczęściej stemple były użytkowane tylko parami. Wiadomo jednak, że najbardziej racjonalne było posługiwanie się zespołami trzech stempli, gdyż górny niszczył się dwukrotnie szybciej od dolnego. Wynika $\mathrm{z}$ tego, że bicie monet niektórych typów przerywano, zanim dochodziło do tego zniszczenia lub najpóźniej, gdy ono następowało. W rezultacie monety rodzime stanowily tylko nieznaczną domieszkę do olbrzymiej masy monet obcych, pozostających na rynku.

Nie zmieniło się też przeświadczenie o braku racjonalnej organizacji mennictwa i jego decentralizacji. Było ono przedsiębrane wielokrotnie od nowa przez różne 
osoby, z wykorzystaniem różnych wzorców i w rozmaitych miejscach. Nie widać też jakiejś stałej kontroli ze strony duchownych nad poprawnością wykonywania legend, w wyniku czego niektóre $\mathrm{z}$ nich są zbarbaryzowane lub wręcz przemienione w pseudolegendy. Zupełnie nie przekonuje domysł M. Boguckiego i J. Magiery, jakoby próbę jakiegoś zreformowania i uzdrowienia polskiego mennictwa miał podjąć następca tronu, Mieszko Bolesławowic, późniejszy Mieszko II. Miał on tego dokonać około 1015 r., po powrocie do Polski z dworu Henryka II i po małżeństwie z Rychezą (Bogucki, Magiera 2015a, s. 124 i n., 128). Nie widać jednak $\mathrm{w}$ tym czasie jakiegoś przełomu $\mathrm{w}$ polskim mennictwie, a początki typu z legendą PRINCES POLONIE, który miał być wynikiem dokonanej melioracji, są wcześniejsze od tej daty. Skromny wygląd monet przypisywanych Mieszkowi oraz brak podjęcia własnego mennictwa po wstąpieniu na tron w 1025 r. również nie przemawiają za jego zainteresowaniem biciem monet.

Niska ocena strony technicznej mennictwa nie tylko została podtrzymana, ale jeszcze wzmocniona. Wygląda na to, że sporządzenie nowego stempla stanowiło niekiedy trudny problem. Przemawia za tym nie tylko bicie monet jednostronnych, ale również czasem maksymalne przedłużanie życia stempli już bardzo zniszczonych. Nie mniej wymowne jest bicie w oficjalnych mennicach monet o stemplach całkowicie sprymitywizowanych, o czym wspomniano już wyżej.

Taki model mennictwa nie ma ścisłej analogii w żadnym $z$ krajów sąsiednich, które mniej więcej $\mathrm{w}$ tym samym czasie rozpoczynały bicie własnych monet. Zarówno w Czechach, jak i na Węgrzech było ono znacznie bardziej rozwinięte i lepiej zorganizowane. Odbywało się w jednym, głównym ośrodku, w dodatku według ujednoliconych wzorów (Suchodolski 1971).

Najbliższy do polskiego był sposób wybijania monet w Szwecji, gdzie również łączono emisje opatrzone poprawnymi legendami z emisjami całkowicie naśladowczymi i o cechach silnie zbarbaryzowanych. Ale w Szwecji odbywało się to w jednej mennicy, mieszczącej się w ośrodku stołecznym, i w dodatku przy całkowitym niemal ujednoliceniu typologicznym. Rozmiary tego mennictwa były też większe niż w Polsce (Suchodolski 1971, s. 157-182; Malmer 1989; 1997; 2000).

Pojawia się pytanie o cel tej całej dosyć zgrzebnej i z trudem wykonywanej produkcji monet. Przypomnijmy jeszcze, że była ona krótkotrwała, gdyż uległa przerwaniu na początku lat dwudziestych XI w. po ćwierćwieczu istnienia - jeszcze przed upadkiem pierwszej monarchii. I w tym przypadku nie ma nowych argumentów przemawiających przeciw mojej dawniejszej hipotezie, że chodziło tu zarówno o zaspokojenie potrzeb ekonomicznych władców, jak i o dokonywanie przez nich manifestacji. O pełnieniu pierwszej z tych funkcji świadczą monety wiernie kopiujące obce wzory, łącznie z imionami i tytułami władców, a nawet $\mathrm{z}$ imieniem mincerza i nazwą jego mennicy. Za rolą manifestacyjną natomiast przemawiają imiona i tytuły książąt polskich, a także współwystępujące z nimi symbole religii chrześcijańskiej. Przedmiotem propagandy zawartej w stemplach było bowiem znaczenie Bolesława Chrobrego i Mieszka Bolesławowica nie jako 
władców suwerennych, ale władców chrześcijańskich, czyli takich, do jakich grona oni również aspirowali. Podobnie oceniają najdawniejsze polskie mennictwo J. Piniński (2012) oraz M. Bogucki i J. Magiera, którzy ostatnio wielce się przyczynili do jego zbadania (Bogucki 2006; 2010; Bogucki, Magiera 2015a). Zdecydowanie natomiast należy się przeciwstawić częstym jeszcze i nawet ostatnio powtarzanym poglądom, że jedynym celem tego wczesnego mennictwa było manifestowanie monarszego statusu władcy (Urbańczyk 2017, 80 n., 331 i passim, por. też wyżej).

Osobny problem stanowi dosyć rozwinięte i funkcjonujące w tym samym czasie w Polsce mennictwo niezwiązane bezpośrednio z władzą zwierzchnią, a przynajmniej nie dające się z nią obecnie powiązać. Chodzi o bardzo różnorodne naśladownictwa monet licznie występujących w znaleziskach na terenie Polski. Od dawna bada je z powodzeniem Peter Ilisch a ostatnio również Mateusz Bogucki (Ilisch 1994; Bogucki 2012a; 2012b; 2012c; 2014). Badacz ten skonstatował, że monety te nie łączą się w większe łańcuchy i dlatego uważa, że wyszły z wielu różnych warsztatów, które były organizowane przez możnych, lokalną administrację (tu imiennie został wskazany Miecław), lub nawet kupców. Prowadzi go to do przekonywającego wniosku, że nie obowiązywało wówczas w Polsce regale mennicze.

I wreszcie sprawa, która pojawiła się dopiero ostatnio. I choć tylko pośrednio jest związana z naszym tematem, jest na tyle interesująca, że warto ją zasygnalizować. Pojawiły się bowiem głosy, że w zakres polskiego mennictwa mogły wchodzić jeszcze inne monety nieksiążęce, a mianowicie najstarsze w Europie Środkowej anonimowe denary biskupie. Chodzi o dobrze już znane monety $\mathrm{z}$ obustronną legendą, odczytaną przeze mnie: Hic denarius est epis[copi] et fav [ore] Bolezai sta[bilis] [ryc. 17]. Dawniej były one jednoznacznie łączone ze św. Wojciechem i drugim okresem jego zasiadania na stolcu biskupim w Pradze (992-994). Obecnie jednak badacze czescy doszli do przekonania, że emitentem był następca Wojciecha Sławnikowica - biskup Thiddag (998-1017). Zwraca wszakże uwagę, że monety te, znane w kilku odmianach stemplowych i co najmniej 15 egzemplarzach, nie wystąpiły dotychczas w żadnym znalezisku, które z pewnością byłoby dokonane na obszarze Czech. Jeden skarb zawierający rzeczoną monetę odkryto natomiast na Węgrzech, a aż dziesięć w Polsce (Suchodolski 2002c; 2018b). Rodzi to oczywistą pokusę, aby uznać, że emitentem był któryś z biskupów polskich, a w owym Bolesławie, z którego łaski doszło do emisji, widzieć nie Bolesława czeskiego (II lub III), ale Bolesława Chrobrego. Ja rozważałem tu kandydatury brata św. Wojciecha, arcybiskupa gnieźnieńskiego Radzima Gaudentego (od 1000 r.) oraz biskupa poznańskiego Ungera. Uznałem przy tym, że osoba pierwszego z nich byłaby tu bardziej wiarogodna. Przemysław Urbańczyk natomiast opowiedział się zdecydowanie za Ungerem (Urbańczyk 2017, 154-156). Sprawę trudno rozstrzygnąc jednoznacznie. Tym niemniej uważam, że obecnie bardziej prawdopodobna jest tradycyjna interpretacja, czyli łączenie tej monety ze 

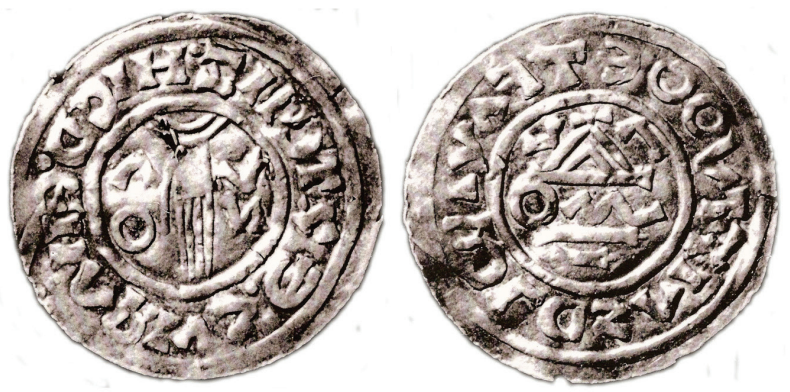

Ryc. 17. Anonimowy denar biskupi przypisywany św. Wojciechowi ze skarbu znalezionego w Lisówku (obecnie zaginiony, foto dzięki uprzejmości Z. Petrania)

św. Wojciechem - przyjacielem cesarza Ottona III, bratem księcia libickiego Sobiesława, który emitował swoje własne monety. Wypływ monet biskupich do Polski można by tłumaczyć wykupywaniem chrześcijańskich niewolników, o czym informują żywoty Świętego (S. Adalberti Vita prior, XII, s. 18 i n.; S. Adalberti Vita altera, XI, s. 10, 12; por. Karwasińska (oprac.), s. 45 i n., 103, 106).

$\mathrm{Na}$ koniec powraca pytanie, jakie zadałem już przed paroma laty. Czy przedstawiony, dosyć specyficzny model polskiego mennictwa nie odbija struktury organizacyjnej państwa $\mathrm{i}$ jakichś trudności związanych $\mathrm{z}$ adaptacją również i innych nowinek zaczerpniętych z Zachodu wraz z chrystianizacją?

\section{BIBLIOGRAFIA}

\section{Źródła}

Epistola Brunonis 1973, Epistola Brunonis ad Henricum regem, Monumenta Poloniae Historica s.n., IV,3, Warszawa 1973, s. 85-106.

S. Adalberti Vita prior 1962, Sancti Adalberti Pragensis Episcopi et Martyris Vita prior, Monumenta Poloniae Historica s.n., IV,1, Warszawa 1962

S. Adalberti Vita altera 1969, Sancti Adalberti Pragensis Vita altera auctore Brunone Querfurtensi, Monumenta Poloniae Historica s.n., IV,2, Warszawa 1969.

Karwasińska J. (oprac.) 1966, Piśmiennictwo czasów Bolesława Chrobrego, Warszawa [polskie thumaczenia powyższych tekstów].

\section{Opracowania}

Beliakov A.S., Ianina S.A. 1977, Kolodezskij klad kuficheskih i zapadnoevropeiskih serebrianyh monet 60-h godov XI v., Numizmaticheskiy sbornik V, 2, s. 10-99.

Blackburn M. 1985, English dies used in the Scandinavian Imitative Coinages, hikuin 11, s. 101-124

Bogucki M. 2006, Nieznana hybryda denara PRINCES POLONIE i nowy typ monety Bolesława Chrobrego, „Wiadomości Numizmatyczne” 50, z. 2, s. 181-194. 
- 2010, Poprawianie stempli monet Bolesława Chrobrego i Mieszka II, „Wiadomości Numizmatyczne" 54 , z. 2, s. $172-192$.

- 2012a, Mennictwo naśladowcze Stowiańszczyzny Pótnocno-Zachodniej w X i XI wieku, „Warszawski Pamiętnik Numizmatyczny" 1, s. 9-20.

- 2012b, Some Polish imitations of Otto-Adelheid-Pfennige, w: G. Dethlefs, A. Pol i S. Wittenbrink (red.), Nummi docent! Münzen - Schätze - Funde. Festschrift für Peter Ilisch zum 65. Geburtstag am 28. April 2012, Osnabrück, s. 111-126.

- 2012c, Zachodniostowiańskie naśladownictwa monet bawarskich z Xi XI w., w: W. Garbaczewski, R. Macyra (red.), Pieniądz i banki na Śląsku, Studia nad dziejami pieniądza i bankowości w Polsce, 2, Muzeum Narodowe, Poznań, s. 85-110.

- 2014, Czy istnieja monety Miecława, zbuntowanego cześnika Mieszka II?, „Notae Numismaticae / Zapiski Numizmatyczne" 9, Kraków, s. 135-144.

Bogucki M., Magiera J. 2015a, New coins of Bolestaw the Brave, „Wiadomości Numizmatyczne” 59, z. 1-2, (Polish Numismatic News IX), s. 115-128.

- 2015b, Lund-Odense-Lund-Kołobrzeg. Danish influences in the „Zemuzil Bomeraniorum “ coinage, w: T. Talvio, M. Wijk (red.), Festskrift till Kenneth Jonsson, Stockholm, s. 119-128.

Garbaczewski W. 2010, W sprawie tzw. „, ukoronowanego orta” na denarze Bolestawa Chrobrego, „Rocznik Polskiego Towarzystwa Heraldycznego” 9 (20), s. 141-149.

- 2015, The Cyrillic penny of Boleslaus Chrobry, prince of Poland - a new source, a new interpretation, „Wiadomości Numizmatyczne” 59, z. 1-2, (Polish Numismatic News IX), s. 95-113.

Ginter T. 1998, Denar „MOGILN CIVITAS”, „Slavia Antiqua” 39, s. 71-79.

Gumowski M. 1939, Corpus nummorum Poloniae, t. 1, Monety Xi XI w., Kraków.

Gorlińska D. i in. 2015, Frühmittelalterliche Münzfunde aus Masowien, Podlachien und Mittelpolen, w: M. Bogucki, P. Ilisch i S. Suchodolski (red.), Frühmittelalterliche Münzfunde aus Polen, Inventar III, Warszawa (= FMP III).

Horoszko G. i in. 2016, Frühmittelalterliche Münzfunde aus Pommern, w: M. Bogucki, P. Ilisch i S. Suchodolski (red.), Frühmittelalterliche Münzfunde aus Polen. Inventar II, Warszawa (= FMP II).

Ilisch P. 1994, Regensburg- und Otto-Adelheid-Imitationen aus Polen, „Wiadomości Numizmatyczne”, 38 , z. 1-2, s. 65-70.

- 2005, Eine polnische oder pommerische Prägegruppe des 11. Jahrhunderts, „Wiadomości Numizmatyczne" 49, z. 2, s. 191-196.

Ilisch P., Suchodolski S. 2003, Eine Erweiterung der Münzserien Bolesław Chrobrys, „Wiadomości Numizmatyczne" 47, 2003, (Polish Numismatic News VII, 2003), s. 97-104.

Jasiński K. [1992], Rodowód pierwszych Piastów, Warszawa-Wrocław b.r. wyd.

Jonsson K., Suchodolski S. 2009, A new coin type of Boleslav the Brave found in Sweden. Wiadomości Numizmatyczne 53, z. 1, s. 29-40.

Kara M., Krysztofiak T. i Wyrwa A.M. (red.) 2016, Gród piastowski w Gieczu. Geneza - funkcja - kontekst, Poznań, Wydawnictwo PTPN.

Kiersnowski R. 1960, Pieniądz kruszcowy w Polsce wczesnośredniowiecznej, Warszawa.

Kollinger K. 2014, Polityka wschodnia Bolestawa Chrobrego (992-1025), Wrocław.

Kossowski M.D. 2007, Orzet ukoronowany na denarze Bolestawa Chrobrego z legenda PRINCES POLONIE - analiza motywu, ,Slavia Antiqua” 48, s. 161-184.

- 2008, Ukorowany orzet Chrobrego z denarów emisji roku tysięcznego - ponadczasowe ujęcie plastyczne wyobrażenia ptaka, „Rocznik Polskiego Towarzystwa Heraldycznego”, nowej serii t. 8 (XIX), s. 3-25.

- 2010, Jaki znowu paw? Niestabilna hipoteza wciąż powraca - rzecz o denarze Bolesława Chrobrego, „Slavia Antiqua” 51, s. 153-164.

Labuda G. 1992, Mieszko II król Polski (1025-1034). Czasy przełomu w dziejach Państwa Polskiego, Kraków, Wydawnictwo PAU, Rozprawy Wydziału Historyczno-Filozoficznego 73.

Magiera J., Stukalova T.J. 2015a, Polskie monety nachala XI veka v kolekcii Otdela Numizmatiki GIM, w: Srednevekovaja numizmatika Vostochnoj Evropy, vyp. 5, Moskva, s. 236-243.

- 2015b, Novye monety Boleslava I Chrabrogo (992-1025), Srednevekovaja numizmatika Vostochnoj Evropy, vyp. 5, Moskva, s. 244-252. 
Malmer B. 1989, The Sigtuna Coinage c. 995-1005, Commentationes de nummis saeculorum IX-XI in Suecia repertis, Nova Series 4, Stockholm.

- 1997, The Anglo-Scandinavian Coinage c. 995-1020, Commentationes de nummis saeculorum IX-XI in Suecia repertis, Nova Series 9, Stockholm.

- 2010, Den Svenska mynthistorien. Vikingatiden ca 995-1030, Stockholm.

Moździoch S., Stanisławski B. i Wiszewski P. (red.) 2013, Scandinavian Culture in Medieval Poland, Wrocław.

Nakielski W. 2012, Propozycja nowej atrybucji monet ślaskich przełomu XI i XII w. w świetle depozytu z miejscowości Kopacz, gm. Złotoryja, w: W. Garbaczewski, M. Macyra (red.), Pieniądz i banki na Ślasku, Poznań, s. 147-184.

Nowak P. 2016, (zap. kryt.) S. Suchodolski, The beginnings of Polish coinage in the light of recent research, Wiadomości Numizmatyczne 59, 2015, z. 1-2 (Polish Numismatic News, IX, 2015), s. 67-94, Studia Źródłoznawcze 54, s. 231 i n.

Panfil T. 2002, Lingua symbolica. O pochodzeniu i znaczeniach najstarszych symboli heraldycznych $w$ Polsce, Lublin, s. 163-200.

Piniński J. 2002, Trzeci egzemplarz monety Bolesława Chrobrego z przedstawieniem strzały, „Wiadomości Numizmatyczne" 46, z. 1, s. 51-58.

- 2010, W sprawie symboliki wyobrażeń i chronologii niektórych typów monet Bolestawa Chrobrego, w: Pieniadz-symbol-władza-wojna. Wspólne dziedzictwo Europy, Augustów-Warszawa, s. 60-71.

- 2012, Jakie były powody emitowania pierwszych monet polskich? Manifestacja czy ekonomia?, w: Pieniądz i systemy monetarne wspólne dziedzictwo Europy, Augustów-Warszawa, s. 70-84.

Polanský L. 2017, Denáry BOLEZLAVS DVX / MOGILN CIVITAS z Národního muzea v Praze, w: M. Bogucki, W. Garbaczewski i G. Śnieżko (red.), Nummi et humanitas. Studia ofiarowane profesorowi Stanisławowi Suchodolskiemu w 80 rocznice urodzin, Warszawa, s. 235-254.

Reyman-Walczak B. 2013, Frühmittelalterliche Münzfunde aus Kleinpolen, w: M. Bogucki, P. Ilisch i S. Suchodolski (red.), Frühmittelalterliche Münzfunde aus Polen. Inventar IV, Warszawa (= FMP IVA).

Stukalova T.J. 2005, Tri denarija polskogo knjazja Meshko I v sobranii GIM, w: XIII vserossijskaja numizmaticheskaja konferencija, Moskva, s. 83-84.

Schmidt T. 1990, Nowa interpretacja denara GNEZDUN CIVITAS, w: Gniezno. Studia i materialy historyczne, t. 3, Warszawa-Poznań, s. 237-245.

Stanisławski B. 2013, Jómswikingowie z Wolina-Jómsborga. Studium archeologiczne przenikania kultury skandynawskiej na ziemie polskie, Wrocław.

Stronczyński K. 1883-1885, Dawne monety polskie dynastyi Piastów i Jagiellonów, cz. 1-3, Piotrków [Reed. Warszawa 2005].

Stróżyk P. 2000, Ikonografia denarów z imieniem Mieszka. Ze studiów nad ceremonialnymi nakryciami głowy pierwszych Piastów, „Roczniki Historyczne” 66, s. 121-134.

- 2009, Uwagi o denarze MOGILN CIVITAS, w: W. Garbaczewski, M. Macyra (red.), Pieniadz i banki w Wielkopolsce, Poznań, s. 41-56.

Suchodolski S. 1967, Moneta polska w X/XI wieku (Mieszko I i Bolestaw Chrobry), Wiadomości Numizmatyczne 11, z. 2-3, s. 65-194.

- 1971, Początki mennictwa w Europie Środkowej, Wschodniej i Pótnocnej, Wrocław.

- 1996, Poczatki mennictwa we Wrocławiu, w: Z. Kurnatowska (red.), Stowiańszczyzna w Europie średniowiecznej, t. 2, Wrocław, s. 121-126.

- 1997, Tadeusza Wolańskiego zwycięstwo zza grobu, czyli nowy typ denara Bolestawa Chrobrego, w: M. Głosek (red.), Archeologia i starożytnicy. Studia dedykowane Profesorowi Andrzejowi Abramowiczowi w 70 rocznice urodzin, Łódź, s. 265-273 (toż z uzupełnieniem w: Suchodolski 2017, s. 571-584).

- 1998, Spór o początki mennictwa w Czechach i w Polsce, „Wiadomości Numizmatyczne” 42, z. 1-2, s. $5-20$.

- 1999, Beware, the fraud! On alleged finds of deniers with the legend GNEZDVN CIVITAS and other coins from the reign of Bolestaw the Brave, ,Notae Numismaticae/Zapiski Numizmatyczne” 3/4, Muzeum Narodowe w Krakowie, Kraków, s. 303-321 (polska wersja w: Suchodolski 2017, s. 41-58). 
- 2000a, Kult św. Wacława i św. Wojciecha przez pryzmat polskich monet z wczesnego średniowiecza, w: Kościót, kultura, społeczeństwo. Studia z dziejów średniowiecza i czasów nowożytnych, Warszawa, s. 87-102 (toż z uzupełnieniem w: Suchodolski 2012, s. 392-409).

- 2000b, Najdawniejsze monety polskie jako źródło dające poznać dzieje pierwszej monarchii, w: Aetas media aetas moderna. Studia ofiarowane profesorowi Henrykowi Samsonowiczowi w siedemdziesiątą rocznicę urodzin, Warszawa, s. 299-312 (toż z uzupełnieniem w: Suchodolski 2012, s. 275-286).

- 2000c, Noch einmal über die Anfänge der Münzprägung in Polen, w: B. Kluge, B. Weisser (red.), XII. Internationaler Kongress Berlin 1997, Akten-Proceedings-Actes II, Berlin, s. 978-982.

- 2000d, Początki rodzimego mennictwa, w: H. Samsonowicz (red.), Ziemie polskie w X wieku i ich znaczenie w ksztaltowaniu się nowej mapy Europy, Kraków, s. 351-360.

- 2002a, Orzel czy paw? Jeszcze o denarze Bolesława Chrobrego z napisem PRINCES POLONIE, w: T. Wasilewski (red.), Inter Orientem et Occidentem. Studia z dziejów Europy środkowowschodniej ofiarowane Profesorowi Janowi Tyszkiewiczowi w czterdziestolecie pracy naukowej, Warszawa, s. 153-169 (toż z uzupełnieniem w: Suchodolski 2012, s. 287-305).

- 2002b, Rex Bolizlavus - tzw. królewskie monety Bolesława Chrobrego, w: A. Rachuba i inni (red.), Heraldyka... i okolice, Warszawa, s. 285-295.

- 2002c, Monety świętego Wojciecha, w: C. Buśko i in. (red.), Civitas \& villa. Miasto i wieś w średniowiecznej Europie Środkowej, Wrocław-Praha, s. 447-452.

- 2005, Włócznia świętego Stefana, „Kwartalnik Historyczny” 112, z. 3, s. 91-110 (toż w: Suchodolski 2017, s. 337-354)

- 2009a, A jednak paw! Uwagi o rzekomych rewelacjach numizmatycznych M.D. Kossowskiego, „Slavia Antiqua" 50, 2009, s. 365-373.

- 2009b, Czy moneta polska ma już tysiąc lat?, w: T. Sawicki (red.), Studia nad dawna Polska, t. 2, Gniezno, s. 27-46 (toż z uzupełnieniem w: Suchodolski 2017, s. 19-40).

- 2010, Le type byzantin aux origines du monnayage en Pologne, w: Mélanges Cécile Morrisson, Collège de France - CNRS. Centre de Recherche d'Histoire et Civilisation de Byzance, Travaux et Mémoires 16, Paris, s. 821-828.

- 2012, Numizmatyka średniowieczna. Moneta źródtem archeologicznym, historycznym i ikonograficznym, Warszawa.

- 2014, Mĕl Gaudentius, bratr sv. Vojtěcha, vliv na polské mincovnictví?, w: Antiqua Cuthna, 3 (2007), Po stopách svatého Vojtěcha, Praha, s. 131-139.

- 2017, Moneta polska i obca w średniowieczu, Warszawa

- 2018a, Gdzie, kiedy $i$ w jakim celu Bolestaw Chrobry emitowal denary z cyrylickim napisem?, w: T. Nowakiewicz i in. (red.), Animos labor nutrit. Studia ofiarowane Profesorowi Andrzejowi Buko $w$ siedemdziesiąta rocznice urodzin, Warszawa, s. 151-162.

- 2018b, Mince svatého Vojtěcha, Folia numismatica 32/1, Supplementum ad Acta Musei Moraviae, Brno, s. 3-15.

Suchodolski S., Bogucki M. 2017, Inwentaryzacja wczesnośredniowiecznych znalezisk pieniądza kruszcowego w Polsce, „Przegląd Archeologiczny” 65, s. 53-68.

Szczurek T. i in. 2017, Frühmittelalterliche Münzfunde aus Grosspolen, w: M. Bogucki, P. Ilisch, S. Suchodolski (red.), Frühmittelalterliche Münzfunde aus Polen. Inventar I, Warszawa (= FMP I).

Urbańczyk P. 2017, Bolesław Chrobry - lew ryczacy, Toruń, Fundacja na rzecz nauki polskiej

Warszawskie Centrum Numizmatyczne (WCN) 2012, Aukcja Nr 52/2012

- 2014, Aukcja Nr 56/2014

- 2019, Aukcja Nr 72/2019 